\title{
The tobacco industry's code of advertising in the United States: myth and reality
}

\author{
John W Richards, Jr, Joe B Tye, Paul M Fischer
}

\begin{abstract}
The major American tobacco companies developed and agreed to abide by the Cigarette Advertising Code in 1964. The stated aims of the code were to prohibit advertising directed at young people, to prohibit advertising that used fraudulent health claims, and to assure compliance with the code's provisions through the establishment of an administrative arm and enforcement mechanism to prescreen and monitor all cigarette advertising. In the 32 years since the Cigarette Advertising Code's adoption, the tobacco industry has used the existence of this code and its revisions and promises of self-regulation in accordance with this code as evidence that it promotes tobacco use only in a responsible manner. The code has served as the basis of the industry's efforts to avoid further local, state, and federal regulatory oversight of its marketing activities. A historical review of cigarette advertising since 1964 indicates that the voluntary code's major provisions have been regularly violated in the spirit and the letter. The administrative and enforcement provisions of the original Cigarette Advertising Code were quietly dismantled soon after the voluntary code's adoption and were completely omitted from the revised code in 1990. The historical evidence indicates that self-regulation of cigarette advertising and promotion by the tobacco industry has been repeatedly given trials and has not worked.
\end{abstract}

(Tobacco Control 1996;5:295-311)

Keywords: legislation; regulation; ethics; advertising; marketing.

University Family Medicine, Augusta, Georgia, USA JW Richards, Jr PM Fischer

Paradox 21, Solon, Iowa

JB Tye

Correspondence to: Dr JW Richards, Jr, 519 Pleasant Home Road, Suite A-3, Augusta, Georgia 30907, USA

"We are proud of the industry's record with respect to cigarette advertising generally and youth in particular. We submit that the record is one of unparalleled restraint and responsibility."-Horace Kornegay, Chairman, The Tobacco Institute.

"Evidence is now available that the 14 to 18 year old group is an increasing segment of the smoking population. RfR must soon establish a successful new brand in this market if our position in the industry is to be maintained over the long term."-RJR's Secret planning assumptions and forecast for the period 1976-1986.

\section{Introduction}

During the past decade, scientific evidence has clearly implicated cigarette advertising iner smoking experimentation by adolescents. ${ }^{3-8_{A}}$ This effect may have its roots in childhood is long before experimentation with cigaretteso actually begins.

Although these findings have been published $\vec{D}$ only recently in the scientific literature, policy makers have expressed concern about the influence of cigarette advertising for over $40 \%$ years. In an effort to forestall legislative or regulatory action that would limit tobaccos advertising and promotion, cigarette manufac-o turers in the United States developed the Cigarette Advertising Code in $1964 .{ }^{10}$ The tobaccos industry has, for the past 32 years, consistentlyo cited its advertising code as a shield agains: recommendations for any increased regulation of cigarette advertising and promotion. The $\overrightarrow{\vec{B}}$ following is an example of the industry's use of $\bar{\beta}$ the code in the legislative arena:

"We have managed to stall HB51, the sampling. ban legislation in the Senate Rules committee. Aक् the same time, we have drafted amendments incor: porating the industry code of ethics. If the sponsor if willing we will attach our amendments to HB51. If he is reluctant we will work to have a separate bilf introduced and keep HB51 bottled up in the Senate $\rho_{0}^{7}$ Rules Committee. ..." (Philip Morris Governmen-'tal Affairs document, 27 January 1989, regarding $\underset{B}{ }$ bill in Utah.)

"All major cigarette companies in the United States claim to follow the provisions of the Cigaretteo Advertising Code." (Letter from Samuel D Chilcote, Jr, President of the Tobacco Institute, March 1991.)

It would be difficult, however, for independ $\widetilde{N}$ ent observers to monitor that claim. The text of the original code was made available to the public once, when it was published on 28 Aprif 1964, on page 50 of the New York Times (appendix 1).

The code was updated and revised in 1990œ and was available for a time in a pamphlet fromo the Tobacco Institute. According to the Tobacco Institute, this revision "combines (1) the provisions of the original Cigarett $\frac{\mathbb{Q}}{\square}$ Advertising Code of 1964, as restated in 1982? (2) the Code of Cigarette Sampling Practices? of 1981, as amended in 1983; and (3) the addio tional restrictions on cigarette advertising anof promotion adopted by the industry in 1990" (appendix 2). The revised Cigarette Advertising Code contains seven provisions relating to advertising, sixteen related to product 


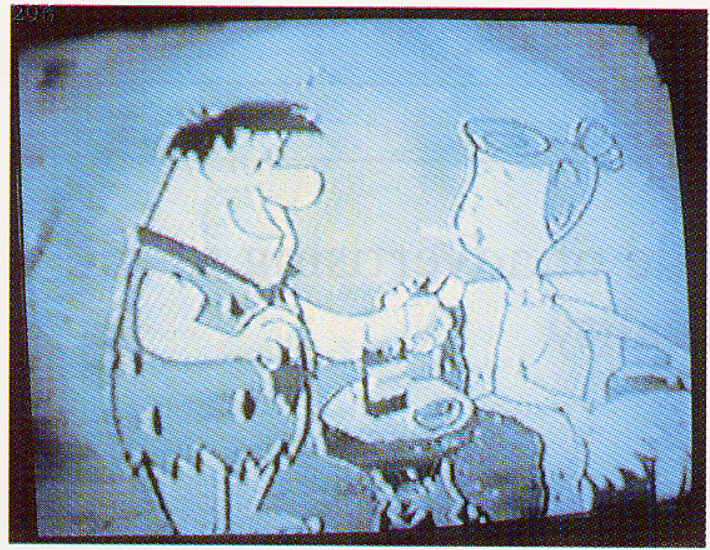

Figure 1 Fred and Wilma Flintstone promote Winston cigarettes in The Flintstones, one of the most popular cartoon series of its time. Today, the Flintstones promote vitamins for children 2 years of age and older.

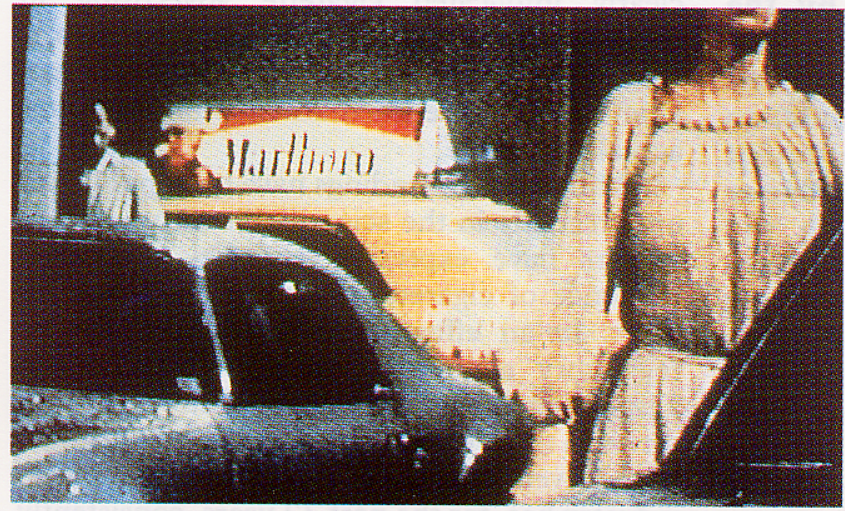

Figure 3 There were 22 paid advertisements for Marlboro in the movie Superman II. Taxis with Marlboro signs were strategically placed for camera exposure and a truck was specially painted to look like a huge Marlboro pack. Additionally, three Kent, two Rich Lights, and a Kool advertisement were seen in the movie.

Figures 12,13, and 14 Comic books aimed at grammar school readers (6-10 years) and junior high (11-14 years) readers also contain tobacco advertisements. The premier issue of NASCUBS (below and bottom right) and the October 1992 (no 485) issue of Batman (right) are illustrated here.

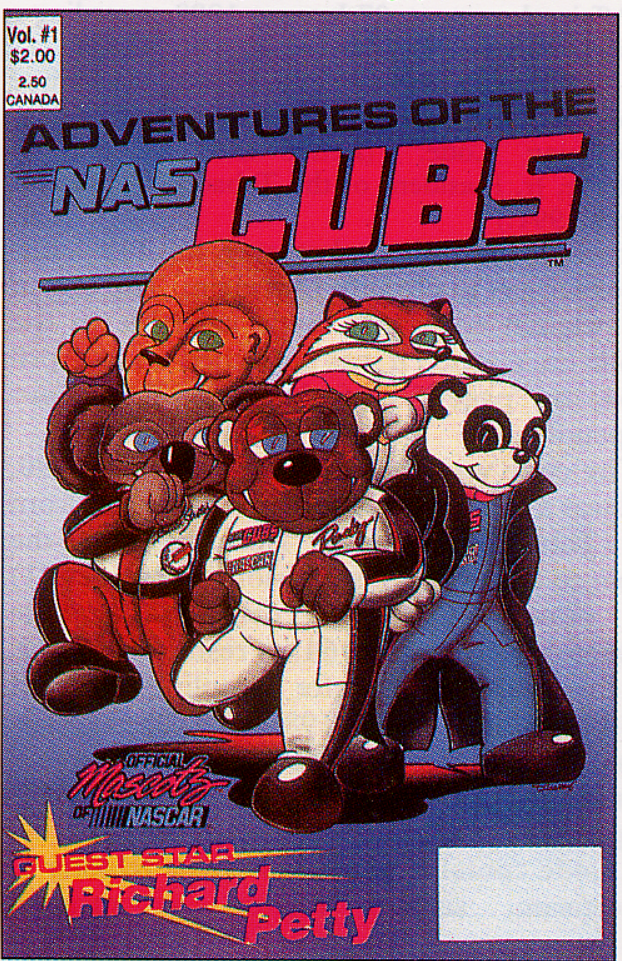

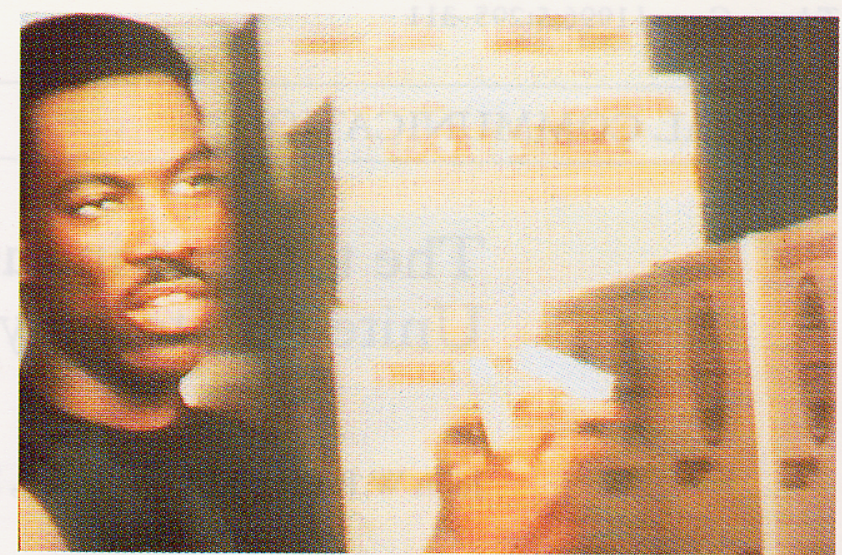

Figure 4 Regarding the Lucky Strikes he was holding in the movie 48 Hours, Eddie Murphy said, "These are very popular with the kids." Product placements extend beyond films themselves when movies are later shown on television and rented on videotapes. This was not mentioned in the code revised by the industry in 1990.

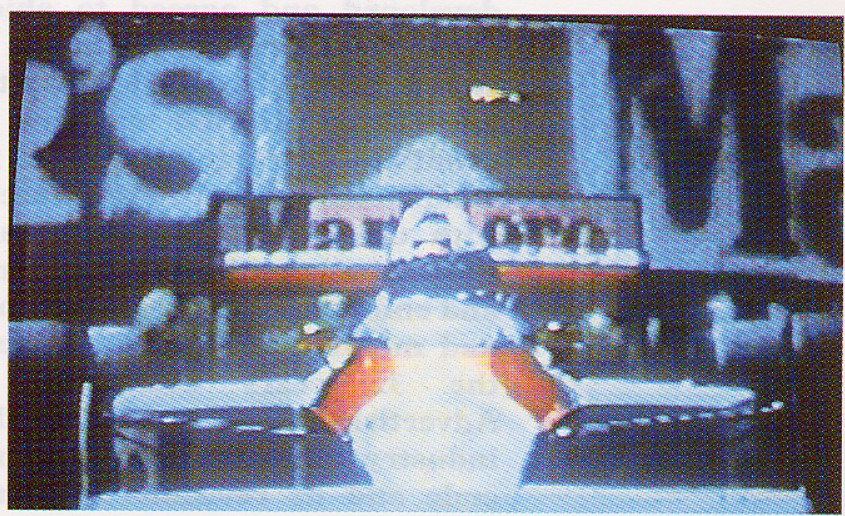

Figure 5 Although Philip Morris claims that it did not authorise the use of its Marlboro trademark in the Super Monaco GP video game, five years after an inquiry by Congress, this arcade game and others still display the Marlboro logo.
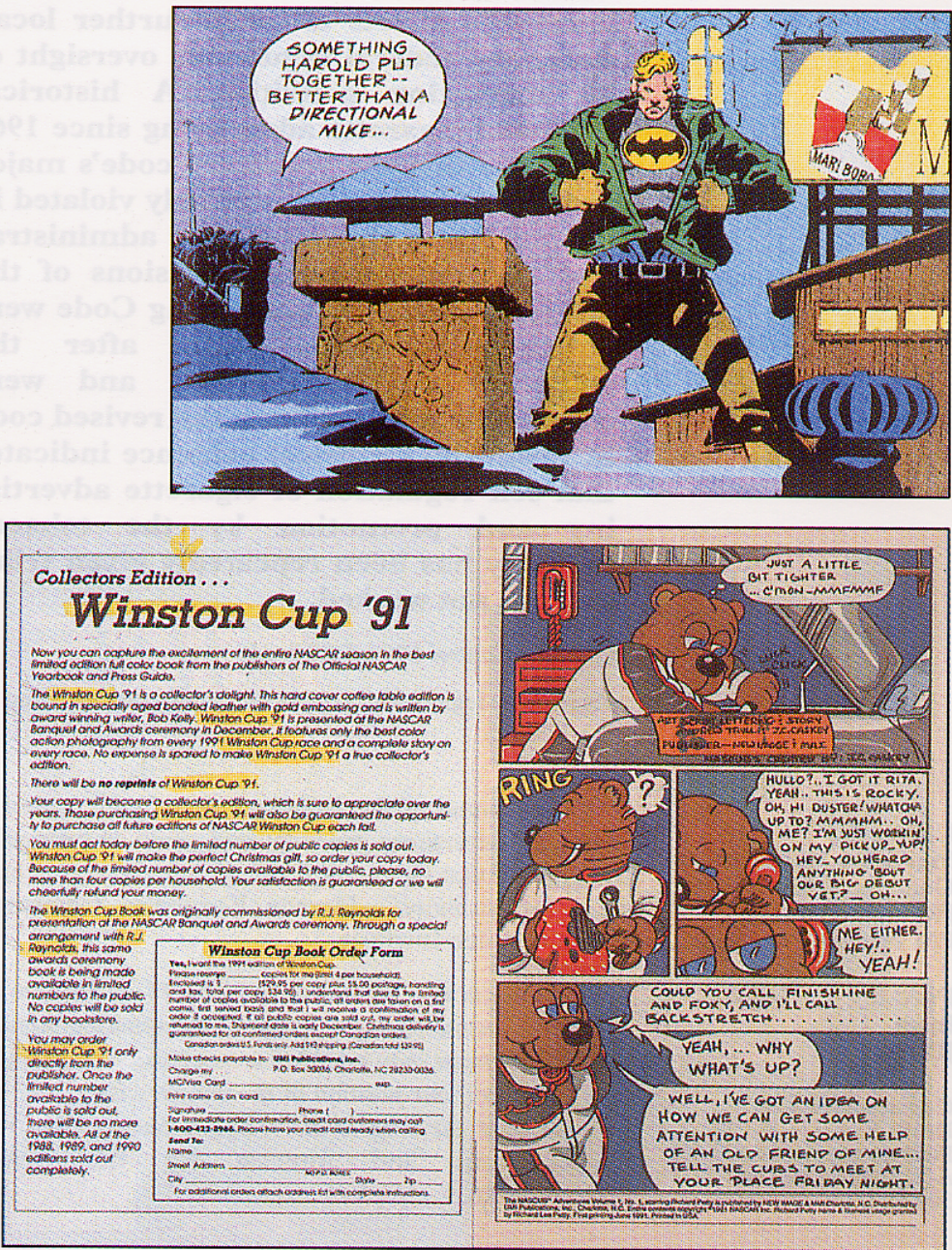
sampling, and three related to other promotional activities. Of note, it omits the original provisions for administrative oversight, enforcement, or penalties (Original code; articles II, III).

In this paper we examine the compliance by tobacco manufacturers with the letter and the spirit of their own Cigarette Advertising Code since its adoption in 1964.

\section{Events leading to the code}

The Cigarette Advertising Code was developed in 1964 by the tobacco industry in response to public complaints about advertising directed at young people and increasing legislative interest in restricting tobacco advertising. Before 1964, competing and misleading health claims saturated cigarette advertising. Some examples include: "More doctors smoke Camels," "Smoke Kent's Micronite filter for the greatest health protection in cigarette history" (the filter is now known to have contained asbestos" ${ }^{12}$ ), and "Play safe with Philip Morris". Public relations reports from the tobacco industry questioned research findings that linked smoking with disease, and attempted to convince the public that people could smoke safely, if only the proper brand was selected. ${ }^{13-15}$

Industry documents that have surfaced are telling:

"Historically, the joint industry funded smoking and health research programs have not been selected against specific scientific goals, but rather for various purposes such as public relations, political relations, positions for litigation, etc." 16

"The Communications Committee is committed to instituting national advertising to reinforce the smoker, his choice to smoke and the custom of smoking. This will be accomplished by: attacking bad research, attacking researchers themselves, where vulnerable. ..."17

Cigarette companies recruited famous athletes, such as Joe DiMaggio, Mickey Mantle, and Bill Tilde; movie stars-for example, Bob Hope, Bing Crosby, Ronald Reagan, and Dorothy Lamour-and other celebrities, such as "famous aviators" and "US Antarctic explorers", to promote their products. Cigarettes sponsored numerous television shows with large audiences of children and teenagers including The Beverly Hillbillies (Winston) and cartoon programmes such as The Flintstones (Winston) (figure 1). ${ }^{18-19}$

As evidence amassed that smoking is hazardous to health, tobacco companies came under increasing criticism for advertising directed toward young people and for attempting to deceive the public into believing that they could smoke without endangering their health. These concerns went as far back as 1952 when a survey of 2200 advertising agency executives asked which advertisements were most objectionable. ${ }^{20}$ The top seven were for cigarettes. These advertisements were criticised primarily for making unfounded health claims.

During the early 1960s, LeRoy Collins, president of the National Association of Broadcasters, criticised cigarette advertising on television. In a 1962 statement, he urged that restraints be imposed against "the use of commercials especially designed to influence the very young and beginning smoker." ${ }^{21}$ In 1963워 he blasted a Lucky Strike campaign which claimed that Lucky Strikes "separate the merD from the boys ... but not from the girls", calling it "a brazen, cynical flouting of the concerns of millions of parents about their children startings the smoking habit."22

The pressure intensified during 1964, the year that US Surgeon General Luther Terry issued the landmark report concluding thap smoking causes premature death from lun\&्ठ cancer and other diseases. ${ }^{23}$ In June of thaj year, the US Federal Trade Commission(FTC) announced that, from 1 January $1965 \vec{\omega}$ it would be an unfair trade practice fo cigarettes to be sold without a warning statings that "Cigarette smoking is dangerous to healthf and may cause death from cancer and othero diseases." 24

In response to this proposed rule (which? never became effective because it was superseded by the federal Cigarette Labeling and Advertising Act of 1965), the nine majos tobacco companies developed and adopted the्ष Cigarette Advertising Code. An article announcing its voluntarily adoption waફ printed in the New York Times of 28 April 1964? In this article, US senator Maurine Neubergef was quoted as saying that the Cigarette Adver tising Code would eliminate "those mosర్ offensive appeals to adolescence an\$ै immaturity which have long scarred the face o\$ the advertising media." 10

\section{Dismantling of the code's enforcement mechanisms}

Almost immediately, it became clear that the Cigarette Advertising Code would not affect the content of cigarette advertisements. On\& extensive retrospective review of cigarette advertising in the print media in 1964 and 1965 reveals that there was no improvement in the advertising claims for any major existing cigarette brand following the adoption of the code. $^{13}$

Former New Jersey governor Robert B Meyō ner was selected by the tobacco companies as the Cigarette Advertising Code administrato and was given authority to fine tobacco compa nies up to $\$ 100000$ in "liquidated damages" foग code violations. In late 1965 , Meyner was critit cised for taking no action when cigarett\& advertisements were run before the Beatleso appearance on the Ed Sullivan Show, which was watched by millions of teenagers. Meyner hac previously ruled that tobacco companies coul@ advertise on family-type television shows watched by children without violating the code. $^{25}$

In 1967, the Cigarette Advertising Code, administrative and enforcement mechanism were dismantled. We have not seen ans evidence that any tobacco company was eve restrained or penalised by Meyner during his. tenure.

In June 1967, the FTC issued a 57-page report on cigarette advertising that criticised the tobacco industry's Cigarette Advertising 
Code as being ineffectual. It concluded that cigarette advertising continued to be deliberately targeted at young people:

"Self-regulation by the industry has proved to be ineffectual. Cigarette commercials continue to appeal to youth and continue to blot out any consciousness of the health hazards. . . . To allow the American people, and especially teenagers, the opportunity to make an informed and deliberate choice of whether or not to start smoking, they must be freed from the constant exposure to such one-sided blandishments and told the whole story."26

The industry has steadfastly maintained that the code's provisions are observed. A letter in March 1991 from Samuel D Chilcote, Jr, President of the Tobacco Institute, to one of the authors (JBT), claimed that all major US tobacco companies continue to comply voluntarily with the code. In a letter to the editor of Advertising Age, published in its 28 October 1996 issue, a spokesperson for the RJ Reynolds Tobacco Company stated, "We have a voluntary code. We adhere to it." ${ }^{27}$ There is, however, no publicly available evidence of any current administrative structure for enforcement of the provisions of the code and the Tobacco Institute admits that no prescreening of any cigarette advertisements is conducted. ${ }^{1}$

\section{Has the industry complied with its own code?}

A review of the industry's advertising practices since 1964 shows that elements of their Cigarette Advertising Code have been violated with great regularity. In fact, the divergence between the provisions of the code and the actual practices of the industry suggests that compliance with the code may never have been intended.

\section{EXAMPLES OF CODE VIOLATIONS \\ Original code $(I V: 1, e)$}

"Natural persons depicted as smokers in cigarette advertising shall be at least twenty-five years of age and shall not be dressed or otherwise made to appear less than twenty-five years of age. ..."

\section{Violation}

Regardless of their chronological age, models are frequently selected who look younger than 25 years of age (figure 2). Studies of cigarette advertising confirm this fact. ${ }^{28-32}$ In the study by Mazis et al, $17 \%$ of 65 models appearing in 50 print advertisements in 1987 had a mean perceived age of less than 25 years. ${ }^{28}$ Furthermore, $49 \%$ of models were judged by at least a quarter of respondents to be less than 25 years of age.

\section{Original code $(I V: 1, a)$}

"Cigarette advertising shall not appear on television and radio programs, or in publications, directed primarily to persons under twenty-one years of age."

\section{Violation}

Tobacco companies regularly target youthoriented media for saturation exposure to cigarette advertisements. A study of cigarette advertisements in popular magazines in 1989 showed that youth-oriented entertainment, glamour, and sports magazines had heavy con- centrations of cigarette advertising. ${ }^{30}$ In a longitudinal review of cigarette advertising from 1960 to 1985, both adult and youth-oriented magazines showed a substantial increase in cigarette advertising. ${ }^{30}$ In fact, Sports Illustrated, which carries numerous tobacco advertisements in each issue, promotes itself as the ideal gift for high school students (14-18 year olds) and a third of its readership is under 21 years of age. ${ }^{29}$

In 1969 , cigarette companies were banned by the US Congress from television advertising (commencing 2 January 1971) because of con-
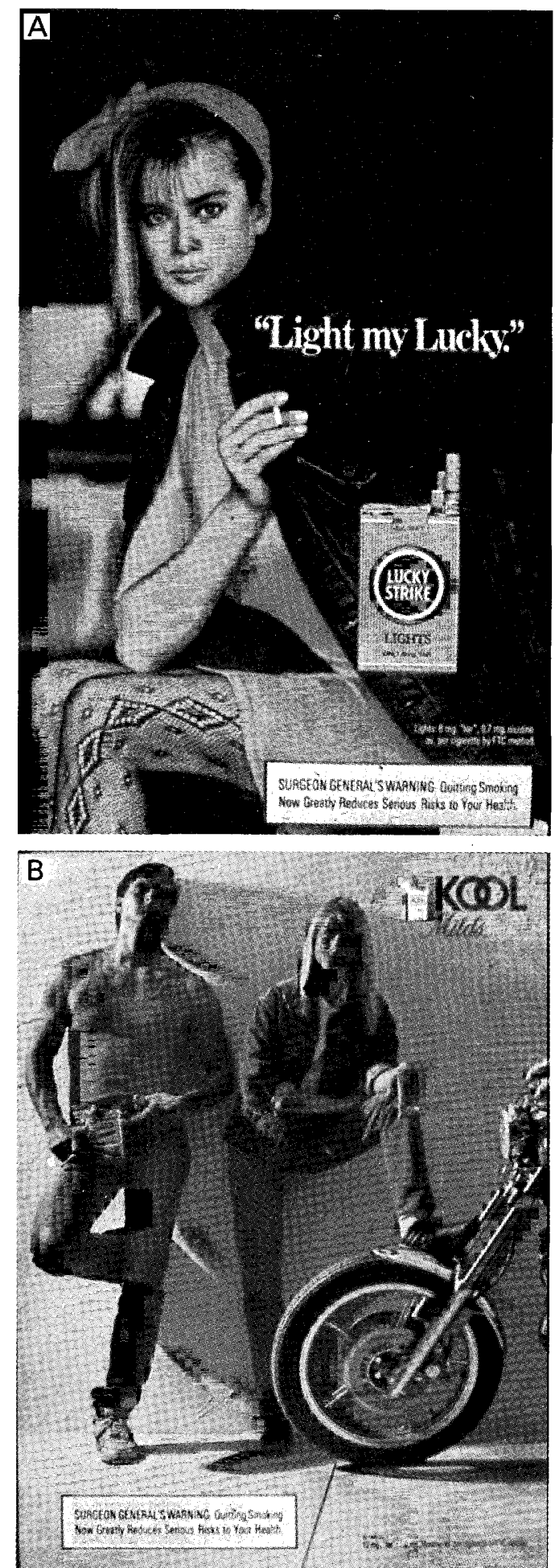

Figure $2 a$ and $b$ Models appearing under age 25 cannot be used to promote cigarettes, according to the Cigarette Advertising Code. 
cerns that such advertising would influence adolescent decisions to smoke. According to an FTC report, "Intentional or fortuitous, teenagers appear to be a prime target for televised cigarette advertising" noting that teenagers viewed 7.8 cigarette-sponsored programmes per week vs 5.9 viewed on average by all persons (teenagers and adults). ${ }^{27}$ This television and radio ban has been successfully circumvented through sponsorship of televised sports events (table 1). Lydia Stephens, ABC sports programme director, said of Philip Morris' sponsorship of Virginia Slims, "I think it's clever. They've found a loophole." " For example, during a single 90 -minute telecast of the Marlboro Grand Prix auto race, the Marlboro logo was shown or the brand "Marlboro" was mentioned 5993 times. $^{33}$ This exposure was estimated by the auto racing industry to have a television air time value of $\$ 1132240 .{ }^{34}$ The US Justice Department recently required Philip Morris to remove cigarette advertising from Madison Square Garden because of its location in relation to TV exposure. ${ }^{35}$ The Justice Department did not address other sports such as auto racing.

Tobacco companies have also arranged for cigarette advertising to be placed in motion pictures, many of which are later shown multiple times on television, including some movies produced for children. Philip Morris paid $\$ 42500$ to have Marlboro cigarettes featured

Table 1 Tobacco-product brand names and sports sponsors

\begin{tabular}{|c|c|}
\hline Sport & Tobacco brand name \\
\hline Auto racing & Winston, Marlboro, Camel, Skoal, Kodiak, etc \\
\hline Drag racing & Camel, Winston, Skoal \\
\hline Formula One & $\begin{array}{l}\text { Marlboro, Camel, Rothmans, Hollywood, John Players, } \\
\text { Gitanes, Mild Seven }\end{array}$ \\
\hline Indy car & $\begin{array}{l}\text { Marlboro, Players, Copenhagen, Hollywood, John } \\
\text { Players, Viceroy, Taryton }\end{array}$ \\
\hline Sprint car & Skoal, Copenhagen \\
\hline Stock car & Winston, Skoal, Kodiak, Levi Garrett, Camel \\
\hline Other racing & $\begin{array}{l}\text { Camel (GT, Motorcycle), Players (Formula Atlantic), } \\
\text { Marlboro (Road Rally) }\end{array}$ \\
\hline Badminton & Winston \\
\hline Baseball & Marlboro, Winston, Kodiak, Red Man, Renegade \\
\hline Basketball & Marlboro, Winston \\
\hline Billiards & Rothmans, Benson \& Hedges, Silk Cut, Embassy \\
\hline Bowling & Winston, Lucky Strike \\
\hline Bowls & Embassy \\
\hline Cricket & Benson \& Hedges \\
\hline Darts & Lucky Strike \\
\hline Fishing & Red Man, Winston, Skoal, Copenhagen \\
\hline Golf & $\begin{array}{l}\text { Vantage, Winston, Salem, Doral, Dunhill, Players, } \\
\text { du Maurier, Benson \& Hedges, Kent, Peter Jackson }\end{array}$ \\
\hline Greyhound racing & Winfield \\
\hline Hockey & Marlboro, Winston, Players \\
\hline Horse racing & Malrboro, du Maurier, Winfield \\
\hline Hydroplane racing & Winston, Camel \\
\hline Monster truck racing & Camel, Skoal, Copenhagen \\
\hline Polo & Winfield, Benson \& Hedges \\
\hline Quarter horse racing & Marlboro, Red Man \\
\hline Rodeo & Skoal, Copenhagen, Winston, Levi Garrett \\
\hline Rugby & Winfield, Rothmans, Marlboro, John Player \\
\hline Sailing & Marlboro, Newport, Kim, Skoal, Copenhagen, Export A \\
\hline Skating & Benson \& Hedges \\
\hline Skydiving & Marlboro \\
\hline Soccer & $\begin{array}{l}\text { Marlboro, Winston, Montana, Camel, Mundial, } \\
\text { Rothmans, Winfield }\end{array}$ \\
\hline Speedboat racing & Marlboro, Players, Export A \\
\hline Stunt flying & Marlboro, Winston \\
\hline Tennis & Virginia Slims, Marlboro, Benson \& Hedges, Salem, Kim \\
\hline Tractor pulling & Red Man, Kodiak, Camel \\
\hline Yachting & Salem, Merit, Vantage, Winston, Export A \\
\hline
\end{tabular}

List compiled by DOC (Doctors Ought to Care). Comment: Sponsorship of sports has allowed the tobacco industry to circumvent the code through television and radio coverage. It also provides the opportunity for enormous free advertising through television, radio, and print media news coverage, brand extenders such as clothing, and "downline" advertising for associated products and services. in Superman II (figure 3, page 296); Liggett and Myers paid $\$ 30000$ to have Eve cigarettes. featured in Supergirl. In one scene from Super응 man II, while a lit Marlboro dangles from her lips, Lois Lane tells a meek Clark Kent that she? will never get sick because she drinks orangeô juice. In the James Bond movie, Licence to Kill a fee of $\$ 350000$ was paid to have a package of Lark appear as a bomb. ${ }^{36}$ In response to criticism of the cigarette promotion, the producer added a Surgeon General's warning after the credits at the end of the movie. ${ }^{37}$ Manyo other youth-oriented movies, including Desper w ately Seeking Susan (Camel), Baby (Marlboro) $\overrightarrow{0}$ Risky Business (Marlboro), Batteries NotIncluded (Salem), Crocodile Dundee (Marlboro) $\vec{\omega}$ and the Walt Disney movies Who Framed Roger Rabbit? (Lucky Strike, Camel) and Honey $k$ Shrunk the Kids (Camel), contain cigarette advertising.

The marketing material for Associated Filmo Promotions states the case clearly: "A feature? film is the most influential medium of our time. The power of films to create trends and? influence lifestyles is enormous.... People identify with motion picture stars and seek to emulate them. ... Your product can be placed exclusively in films that target your specifice demographic audience [emphasis added].' Follow-up market research includes children as young as 12 years old. ${ }^{38}$

When the practice of product placement ino movies, television shows, and music videos waš initially brought to public attention, it was denied by the tobacco industry. ${ }^{39}$ However $\overrightarrow{\vec{D}}$ when questioned later by a Congressiona $\mathrm{B}$ committee, Philip Morris admitted to engaging in placement of its cigarette brands in movies? An aide to former Congressman Thomast Luken added, "They also pay to get generah smoking scenes, particularly on television programs." 39 Following this public disclosure the Cigarette Advertising Code was amended? in 1990 to prohibit tobacco companies from paying for movie placement. However, neither paid placements in television programmes nor unpaid placements in movies or television programmes (figure 4, page 296) are prohibited. ${ }^{39-40}$ Nor is placement advertising in? theatres or payments directly to producers $\frac{D}{0}$ crews, or actors (table 2). For example documents have surfaced that reveal that Brown \& Williamson paid more than $\$ 300$ N million for Kool Jazz advertisements in 4185 theatres, which reached 334.9 millionmoviegoers. $^{41}$ FTC chairwoman Janet Do Steiger has referred to the "unexplaineof appearance of cigarette logos in video arcade? games" as an example of possible targeting of children. ${ }^{42}$ So far, eight video arcade games three home computer games, and two home? video console games have been found to contain cigarette logos (figure 5 on page 2960 table 3). ${ }^{434}$ Dave Rosen, co-chairman of SEGA of America, Inc., makers of Super Monaco GP, issued an official statement which said that the Marlboro logos were "simply a game designer's innocent attempt to mimic real-life locations as scenery to enhance the realism of game play." 45 
Table 2 Tobacco-product placement in movies

\begin{tabular}{lrl}
\hline & Value (US\$) & Examples \\
\hline $\begin{array}{l}\text { Rhinestone Cowboy, Godfather } \\
\text { III, Rambo, 50/50, Rocky IV }\end{array}$ & & $\begin{array}{c}\text { Sylvester Stallone: jewellery, watch, car, horse; } \\
\text { property master: cash; producer: cash; Autistic } \\
\text { Children Foundation: donation }\end{array}$ \\
Harry E Son & 100000 & $\begin{array}{l}\text { Paul Newman: air travel, car } \\
\text { Never Say Never Again }\end{array}$ \\
Where the Boys Are & 20000 & Sean Connery: jewellery \\
Tempest & 100000 & \\
Shaker Run & 70000 & \\
Blue Skies Again & 5000 & \\
Sudden Impact & 7500 & \\
Tank & 50000 & \\
Smokey and the Bandit III & 25000 & \\
Licence to Kill & 10000 & \\
Superman II & 350000 & \\
\hline
\end{tabular}

\section{Sources:}

Hilts PJ. Company spent $\$ 1$ million to put cigarettes in movies, memos show. New York Times 1994 May 20: A16.

Lardman J, Considine M. Giving the name away: Product placement in popular cinema. QUIT and Australian Teachers of Media, 1992.

Ripslinger J. Letter summarising agreement between Stallone with AFP on behalf of Brown \& Williamson. URL: <www.library.ucsf/edu/tobacco/docs/html2401.12>

Stallone S. Agrees to use Brown \& Williamson products in 5 films for $\$ 500000$

URL: <www.library.ucsf/edu/tobacco/docs/html2404.02>.

Coleman J. Re: Apocolypse Now-Marlboro. URL: <www.library.ucsf/edu/tobacco/docs/ html2400.13>

Comment: Whether for direct or indirect compensation, the planned appearance of products and behaviours such as smoking in films and television has been occurring for many years. The relaxed, unaware audience is particularly vulnerable because they think they are in the theatre or watching a show to be entertained, not sold to.

Table 3 Tobacco-product placement in video games

\begin{tabular}{|c|c|c|c|}
\hline Video game & Company & Brand & Format \\
\hline $\begin{array}{l}\text { Sunny Shine: on the } \\
\text { Funny Side of Life }\end{array}$ & Philip Morris & L\&M & $\begin{array}{l}\text { PC, Amiga, Atari, } \\
\text { Commodore }\end{array}$ \\
\hline OutRun & Sega & Marlboro & Arcade \\
\hline Hang On & Sega & Marlboro, John Player Special & Arcade \\
\hline Super Hang On & Sega & Marlboro, John Player Special & Arcade \\
\hline Monaco GP & Sega & Marlboro & Arcade \\
\hline Super Monaco GP & Sega & Marlboro & Arcade \\
\hline Pole Position & Namco & Marlboro & Arcade \\
\hline CHASE HQ & TAITO & Winston pack & Arcade \\
\hline Ferrari Formula One & Electronic Arts & Marlboro & $\begin{array}{l}\text { PC, Amiga, } \\
\text { Commodore }\end{array}$ \\
\hline Final Lap* & Namco, Atari & $\begin{array}{l}\text { Marlboro, Camel, John Player } \\
\text { Special, Rothmans }\end{array}$ & Arcade \\
\hline Final Lap* & $\begin{array}{l}\text { NEC, } \\
\text {. Turbografx }\end{array}$ & Marlboro, Camel & $\begin{array}{l}\text { Arcade, Home } \\
\text { console }\end{array}$ \\
\hline $\begin{array}{l}\text { A1 Unser, } \mathscr{f r}, \text { Turbo } \\
\text { Racing }\end{array}$ & Nintendo & Marlboro & $\begin{array}{l}\text { Genesis, Home } \\
\text { console }\end{array}$ \\
\hline F1 Challenge & Sega & Marlboro & \\
\hline
\end{tabular}

$\mathrm{PC}=\mathrm{DOS}$, Windows or Macintosh formats

${ }^{\star}$ Final Lap is distributed by two companies.

Comment: The appearance of every pixel in a video game is planned by a programmer.

Tobacco-product placement in video games has not yet been investigated systematically.

However, if the occurrence of tobacco-product brand names and logos in video games is simply the result of a programmer's attempt to mimic reality, then it is a sad commentary on reality.

Although in 1989 Philip Morris directed SEGA to "cease all such usage and that you recall all games currently existing in the marketplace", a number of conversations by one of the authors (JWR) with video arcade operators suggest that this was never done.

Are arcades for children and teenagers an expanding advertising venue? Newport basketball games ${ }^{4647}$ and other tobacco advertisements can also be found in arcades. In fact, Philip Morris has produced its own video game, described as "an adventure game in which Sunny talks with people and walks around in a cartoon setting... stuffed with open and hidden advertisements for Liggett \& Myers ( $L \& M$ ) cigarettes. In the game, $L \& M$ posters hang on building walls and in shopping centers. $L \& M$ cigarettes are mentioned in the game's dialogue, cartoon characters appear on the computer scene to borrow cigarettes, and packets of L \& M's appear over and over again.." ${ }^{48}$ The game, currently available in Germany, Switzerland, and Austria, was the idea of the public relations department of $L \& M$ in Munich, Germany. Still unexplained is how a Marlboro billboard appeared in a Batman comic book ${ }^{49}$ geared for readers aged 9 to $17 .^{50}$

\section{Original code (IV: $1, b, c)$}

"Sample cigarettes shall not be distributed to persons under 21 years of age. ... No sample cigarettes shall be distributed or promotional events conducted on school, college, or university campuses, or in their facilities or in fraternity or sorority houses."

\section{Code}

"Cigarette samples shall not be distributed by mail without written, signed certification that the addressee is 21 years of age or older, a smoker and wishes to receive a product sample.... Cigarette samples shall not be distributed in direct response to requests by telephone."

\section{Violation}

One of the functions of tobacco giveaway campaigns is to attract young first time users. During 1988 , the tobacco industry was projected to spend $\$ 876$ million giving away sample cigarettes, ${ }^{51}$ an amount equivalent to 16 free packs for every adult smoker in America, up from $\$ 265$ million the year before. ${ }^{26}$

There is considerable documentation that tobacco company representatives provide free cigarettes to underage minors. (Note: The cigarette industry's code defines a minor as under 21. The smokeless tobacco industry's code defines a minor as under 18.) In a study by Davis and Jason, ${ }^{52} 20 \%$ of the high school students said they had been given cigarette samples and $50 \%$ had seen other minors receiving samples.

Tobacco company coupons and mail distribution campaigns reach young people. When coupons are redeemed at a local store, no signature is required, and when redeemed through the mail, verification of age is impossible. ${ }^{26}{ }^{52-54}$ One technique is to publish a freephone (toll-free) number that anyone claiming to be 21 years of age or older can call and have free cigarettes sent to any address.

That minors are the target of many cigarette coupon programmes was suggested by a 1989 RJR Nabisco advertisement featuring the Camel cigarette cartoon character. The four-page advertisement featured "foolproof dating advice" and "how to impress someone at the beach". One tip suggested that a young man abduct a girl from the beach, "kicking and screaming" against her will. This advertisement also had a coupon for a free pack of cigarettes and suggested that those people who did not like to redeem coupons (underage teenagers?) should recruit "a kind-looking stranger" for this purpose (figure 6). Until 1964, cigarettes were one of the most heavily advertised products on college campuses. Upperclassmen were hired to give free cigarettes to incoming freshmen. Marlboro was apparently a top-selling cigarette among college students long before it was number one in total market sales. Although there is no evi- 
dence that tobacco companies currently supply sample cigarettes at college events, this does not appear to be true for smokeless tobacco. The smokeless tobacco industry's voluntary code uses the cut off of 18 years, no doubt to allow it to conduct its college marketing campaign. US Tobacco distributes Skoal and Copenhagen smokeless tobacco and, until recently, ZigZig rolling papers. The company was one of the original signers of the Cigarette Advertising Code in 1964. Its College Representative Manual (31 July 1985, revised 13 March 1992) lists as a goal: "Create new users of US Tobacco's smokeless products." "All your activities around campus will focus on consumer sampling. ... It is a fact that the only way to create a new user of our product is by having the consumer actually try the product. . . . Sampling should be conducted at social events, fraternity parties, student unions and wherever students congregate." In the accompanying US Tobacco "College Representative Training Video", Dick Kleicko, former professional football player, states that
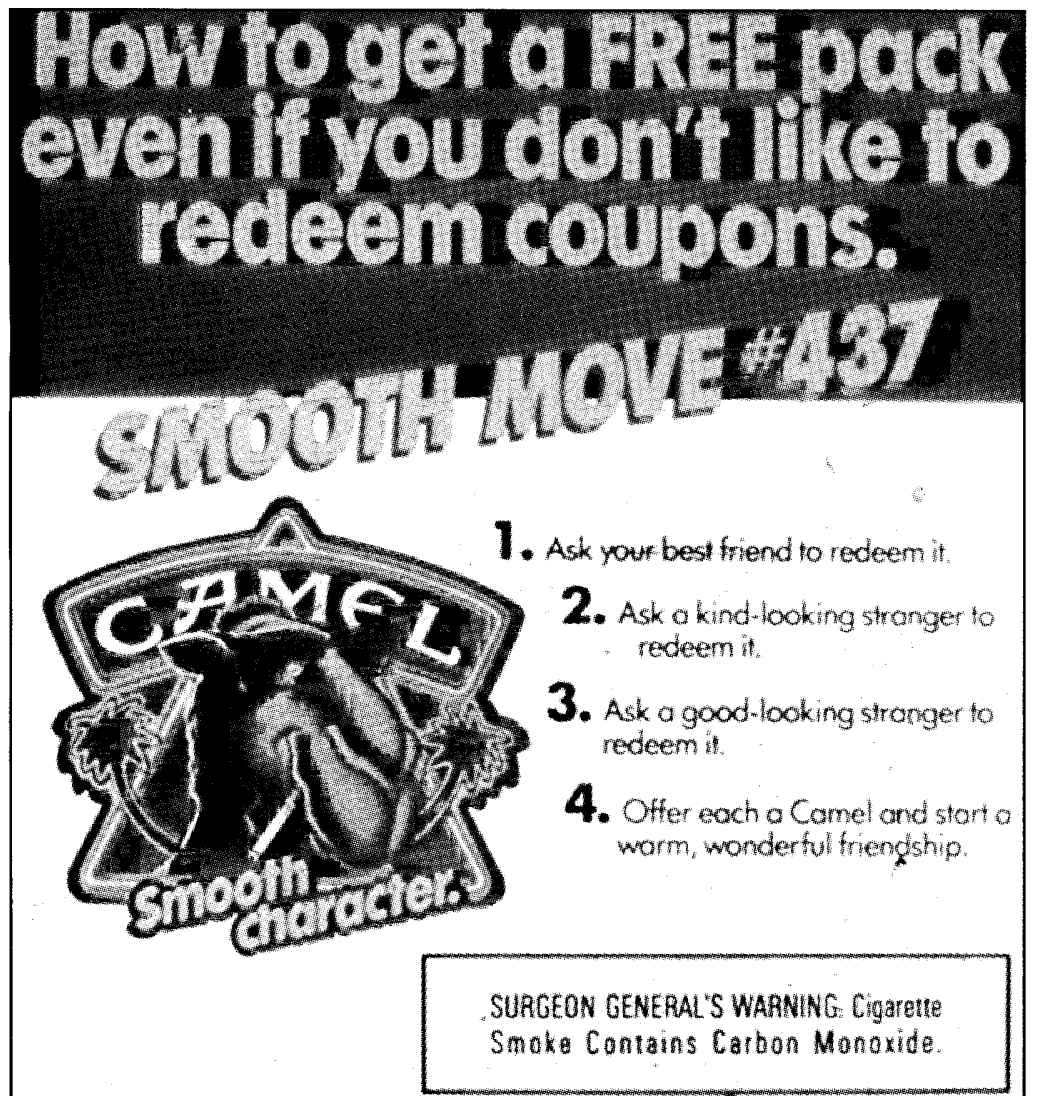

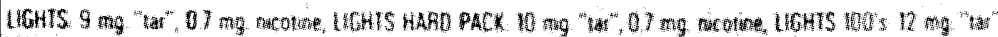

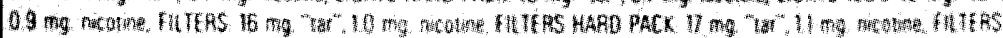

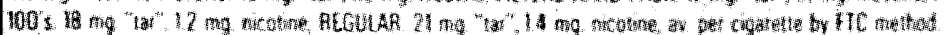

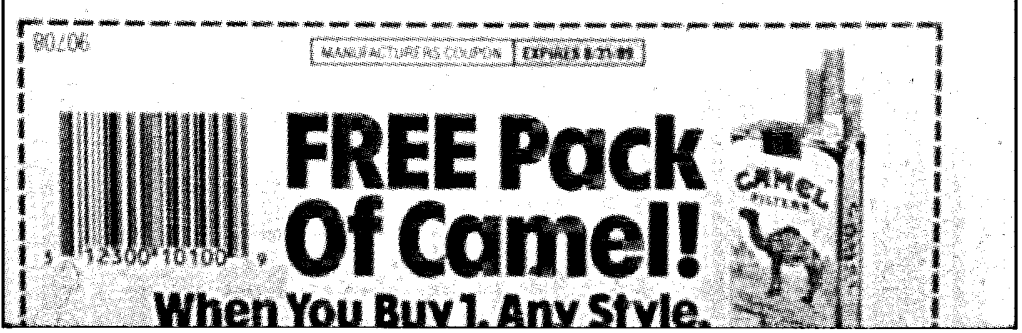

Figure 6 One page of the Camel beach advertisement instructs shy readers how to get Camels for free. he enjoys working for US Tobacco because "the product is so popular with the kids".

Cigarette companies appear to be aware of locations near high schools and colleges where "young adults" (the industry's term) purchaseo cigarettes. In a 1991 letter to staff members, JP McMahon, division manager for RJ Reynolds, requested that sales representatives identify stores in which young people buy cigarettes to make sure that promotional gift items were always available as rewards:

"I need all of you to study the attached scroll list of monthly accounts in your assignment that are presently doing more than $100 \mathrm{CPW}$ for purposes ofis denoting stores that are heavily frequented by young $\overrightarrow{0}$ shoppers. These stores can be in close proximity tocolleges, high schools or areas where there are a largew number of young adults frequenting the store [sic] The purpose of this exercise, is to be able to identify those stores during 1991, where we would try to keep premium items in stores at all times. ... [B]y now I would think that you would have a good feel-r ing on the subject."

Despite RJR's claim that this Florida case wasunique and in violation of policy, it also occurred in Oklahoma in a memo from RJR division manager RG Warlick, who urged 3 emphasis on sales calls to stores "locatedळ across from, adjacent to [or] in the vicinity of the High Schools". ${ }^{5}$

The use of brand-specific gifts, such as caps teeshirts, and mugs, reflects the growing trendo toward promotional marketing. Camel's "Camel Cash Giveaway" and Marlboro's "Geto the Miles, Get the Gear" promotions are the्ष most recent examples of incentive programmes that are designed to reward the behaviour of purchasing cigarettes. ${ }^{56-58}$ The purpose of these giveaways was summed up by John Rosano who runs a dozen Marlboro Adventure Teamvans in New York: "You're trying to con the younger smokers to switch to Marlboro". ${ }^{59}$

\section{Original code $(I V: 1, d)$}

"Cigarette advertising shall not represent that cigarette smoking is essential to social prominence distinction, success, or sexual attraction."

\section{Violation}

Social prominence, distinction, success, ando sexual attraction were recurring themes in cigarette advertising long before 1964. The Cigarette Advertising Code has done nothing to alter this.

Barclay advertisements feature a James $N$ Bond-like character in a tuxedo. Ritz featuresw thin, beautiful women in evening gowns (figure 7). The brand name itself connotes sociale prominence. Vantage advertisements duringe the early 1980 s pictured affluent young people and the symbols of their success such as expensive homes and fancy cars. The tag line⿰氵 proclaimed Vantage to be "The Taste of Success". Implicit promises of sexualo attraction are common in cigarette advertisements (figure 8). Newport, in its long-runningo "Alive with Pleasure" campaign, typically features a young couple or a young man witho two young women, in a sexually suggestive ${ }^{+}$ situation. Salem advertisements of the 1980 s depicted muscular surfers and bikini-clad girls. 


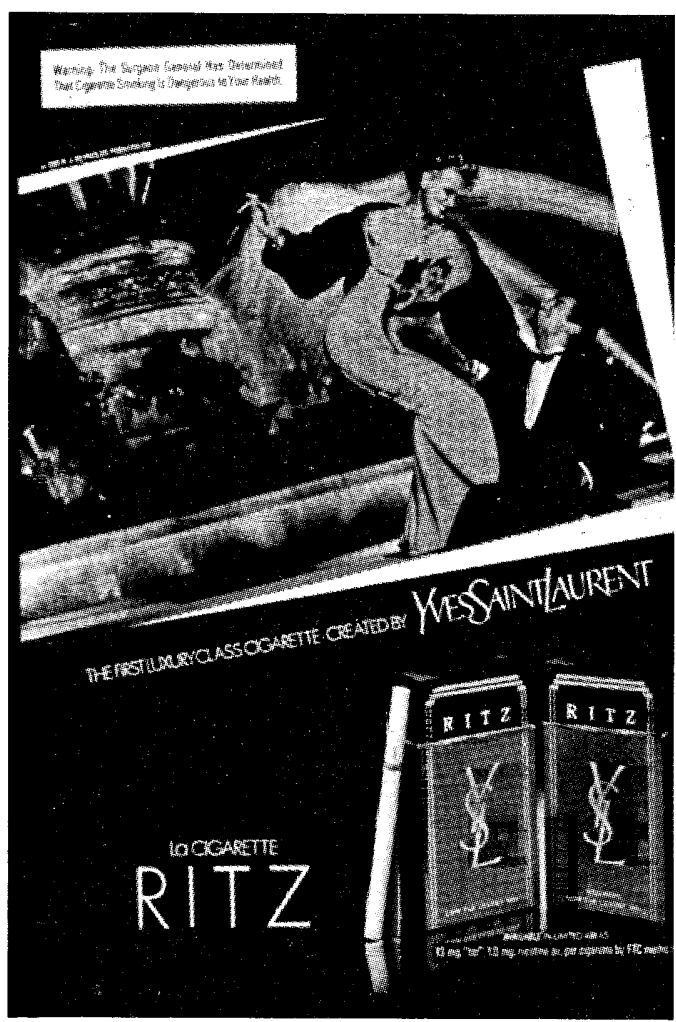

Figure 7 "Social prominence, distinction, success, or sexual attraction" cannot be depicted in cigarette advertising, according to the Cigarette Advertising Code.

Sexual attraction is a dominant theme in much of the advertising for "feminine" cigarettes. Virtually all cigarette brands targeted at females feature words like "Slim", "Thins", "Light", or "Ultralight" in their titles. The advertising imagery features, without exception, thin, beautiful, young models. The implication is that smoking results in physical attractiveness and is an appropriate, effective dieting alternative. More cigarettes-with the

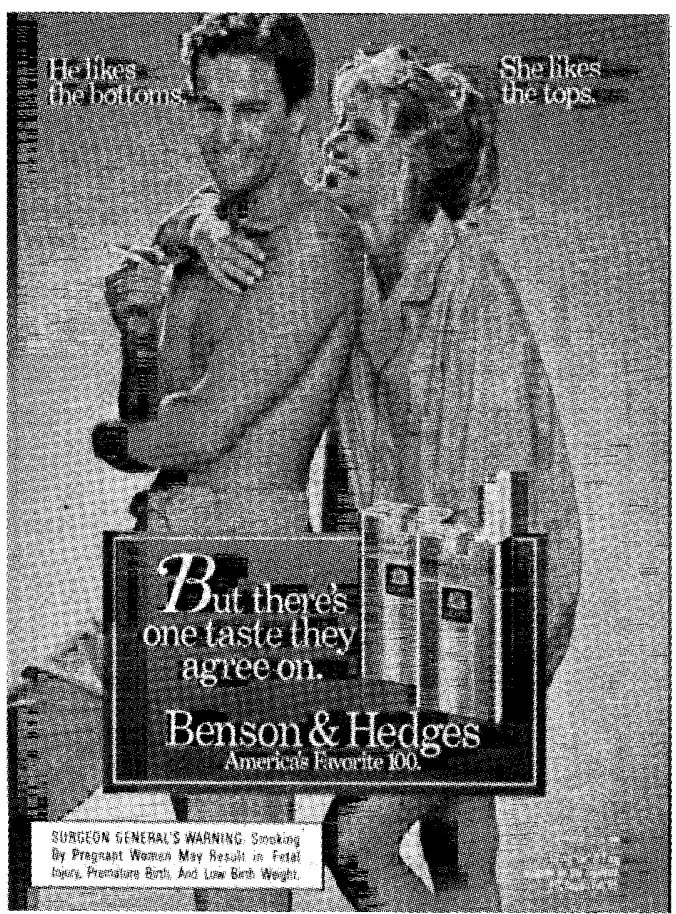

Figure 8 Sexual imagery in this Benson $\mathcal{E}$ Hedges advertisement, in which "He likes the bottoms" and "She likes the tops". slogan "I'm More satisfied"-are more obvious (figure 9).

\section{Original code $(I V: 1, h)$}

"Cigarette advertising shall not depict as a smoker any person well known as being, or having been, an athlete. ... Testimonials from athletes or celebrities in the entertainment world, or testimonials from other persons who ... would have special appeal to persons under twenty years of age, shall not be used in cigarette advertising."

\section{Violation}

A letter of 12 June 1990 in the Wall Street Fournal by a Philip Morris vice president claimed: "We do not have celebrities or athletes endorse cigarettes in our advertising". ${ }^{60}$ Yet at the very same time, Philip Morris was running Marlboro advertisements in Sports Illustrated and other youth-oriented publications featuring Indianapolis 500 racing car winners Danny Sullivan and Emerson Fittipaldi (figure 10). In selected issues of Sports Illustrated there was an eight-page foldout poster of Sullivan and Fittipaldi with their Marlboro racing cars. The Surgeon General's warning was printed on the back, the side most children would tape toward the wall. Danny Sullivan has appeared with his Marlboro Indy car on a playing card from Sports Illustrated for Kids, a magazine developed specifically for children (figure 11).

From a broader perspective, by sponsoring athletic events, tobacco companies convert athletes into implicit endorsers of cigarettes. The women who play in the Virginia Slims tennis tournament and the men who race in the Winston and Camel racing events lend their name, physical prowess, and athletic achievements to the promotion of cigarettes.

Every time an athlete accepts an award or support from a tobacco company with "I'd like to thank [insert brand]", a testimonial occurs. Athletes such as Martina Navratilova help Philip Morris promote its tennis-sponsoring brand by saying, "I'm not telling people to smoke. But if they're smoking, they might as well smoke Virginia Slims, because they're the best." ${ }^{61}$ Tobacco has all but taken over one sport, auto racing, with sponsorship of individual races, cars, and related events. Spin offs from NASCAR's "The Winston Cup" range from the TNN cable network show (formerly Inside Winston Cup, now Inside $N A S C A R$ ), to pure "Winston Cup" spring water as well as comic books and NASCUBS, a promotion for children of an age that still find stuffed animals appealing (figures 12-14, page 296). Analysis of Vortex comic issue no 1 revealed that Winston was mentioned by word or logo 47 times, Skoal (snuff) once, Kodiak (snuff) 24 times, and various beers 70 times. $^{62}$ NASCUBS' first comic book edition mentioned Winston 27 times. $^{63}$

Actor James Colburn has appeared in youthoriented television commercials for Lark cigarettes in Japan. * American cigarette brands have sponsored musical concerts shown on television in Asia, and advertisements have

*Videotape available from Dr Ronald Davis or Dr Gregory Connolly. 


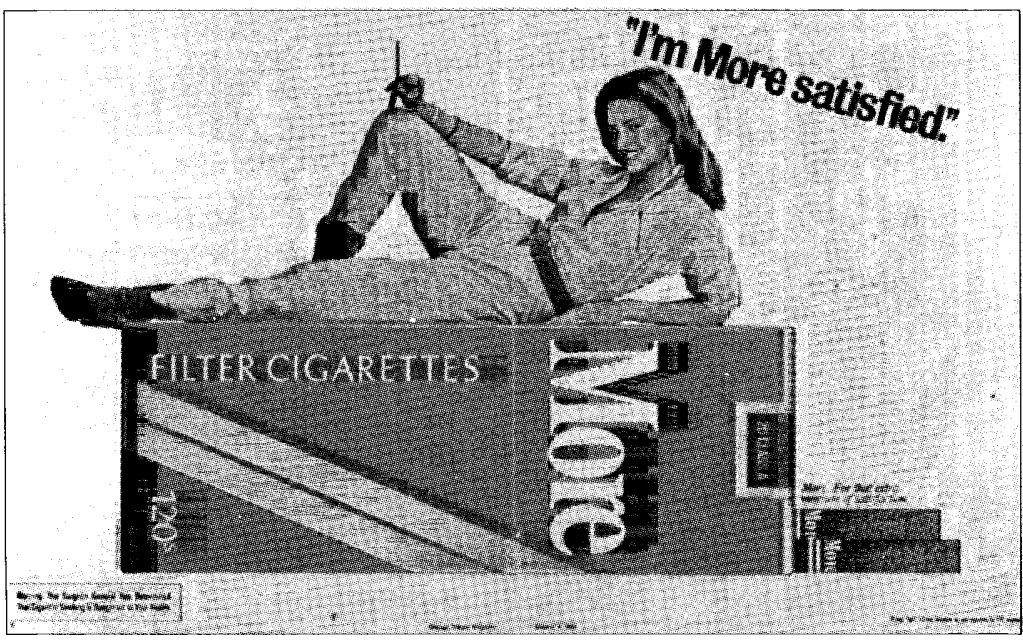

Figure 9 The model, the dress, the pose: Can "I'm More satisfied" be referring to something besides the nicotine?

featured both the cigarette logo/brand name and pictures of rock stars-for example, Paula Abdul, Madonna, and Bon Jovi. ${ }^{59}$ Smokeless tobacco advertisements have featured Walt Garrison, Tom Seaver, Charlie Daniels, and many other celebrities and sports figures. ${ }^{6465}$

\section{Original code $(I V: 1, i)$}

"Cigarette advertising shall not depict as a smoker any person participating in, or obviously having just participated in, physical activity requiring stamina or athletic conditioning beyond that of normal recreation."

\section{Violation}

Many young people may refrain from smoking because of fear of impairing their athletic performance, as documented in a study funded

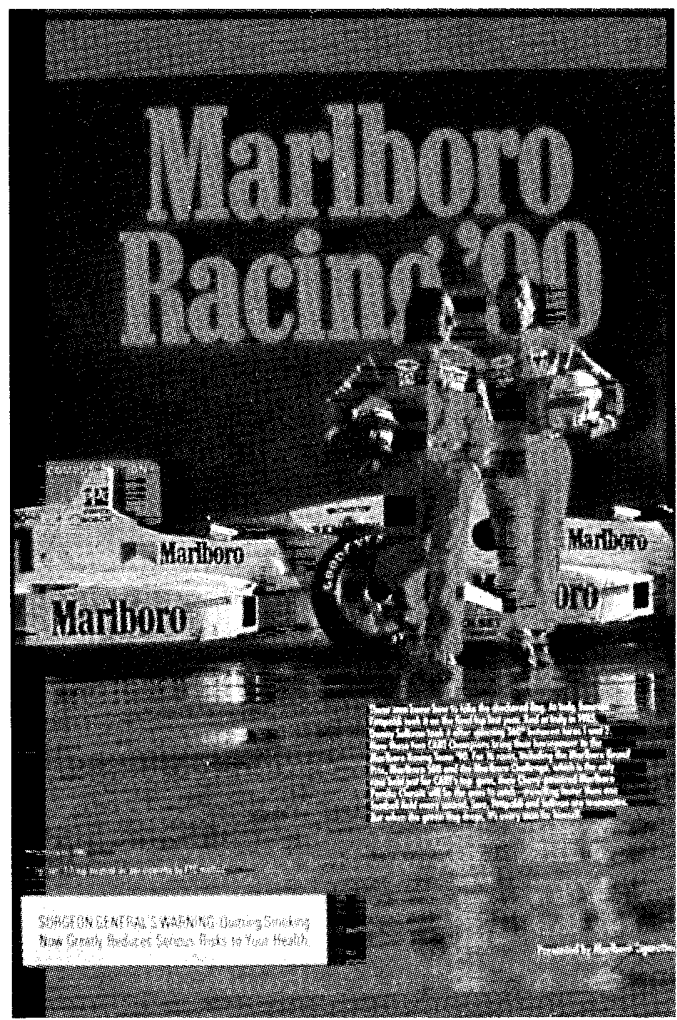

Figure 10 Tobacco companies claim that sports sponsorship is not advertising.

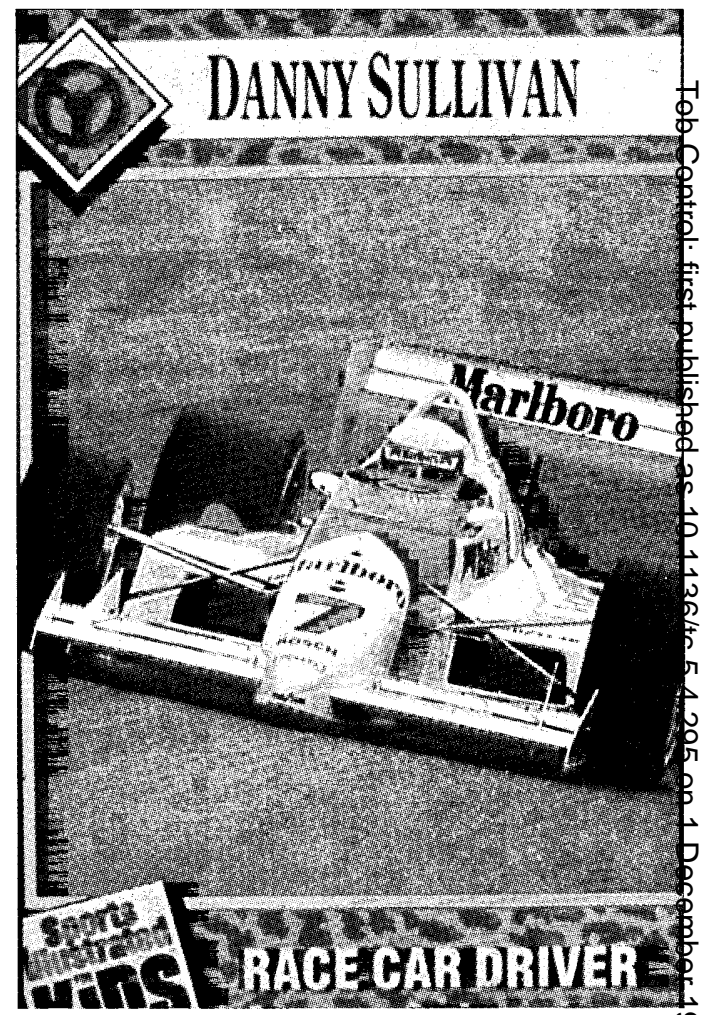

Figure 11 Danny Sullivan is an athlete, a celebrity, and 5 human billboard for Marlboro. He must also have special appeal to "persons under twenty one" because otherwise, Sports Illustrated for Kids would not have selected him for one of its trading cards.

by the tobacco industry's Council for Tobacç్ Research. ${ }^{66}$

Beyond simple sports sponsorship, cigarette advertisements routinely violate this provision? of this code. Perhaps the most egregious exam ples are from the campaign by RJR Nabisco to promote Vantage cigarettes, wherein profeso sional athletes, including downhill ski racers aerobic dancers, windsurfers, kayakers, an other daredevils are pictured in scenes of obviê ous athletic achievement, and the Marlbor Adventure Team where dirt-biking, rafting and horseback-riding through the wilderness is fea tured. In some cases athletes are shown smoki ing, either just before or just after seemingl vigorous sports activity (figure 15).

Original code $(I V: 2, a ; 3 ; 4)$

"No cigarette advertisement which makes a repreN sentation with respect to health shall be used unless [having first been approved by the code administras tor]." "The description or depiction of a filter, shate not be deemed a representation with respect t health. ..." "No cigarette advertising shall be used which refers to the removal or the reduction of an ingredient in the mainstream of smoke of cigarette. ..."

\section{Violation}

For more than seven decades, cigarettes have been promoted with implied or direct claims of safety. ${ }^{67}$ Viceroy used slogans such as "Filtere $\Phi$ cigarette smoke is better for your health. (1951 and 1952); "For greater healt检 protection get Viceroy with the new Health Guard filter." (1952); and "Safer for your throat, safer for your lungs than any other 

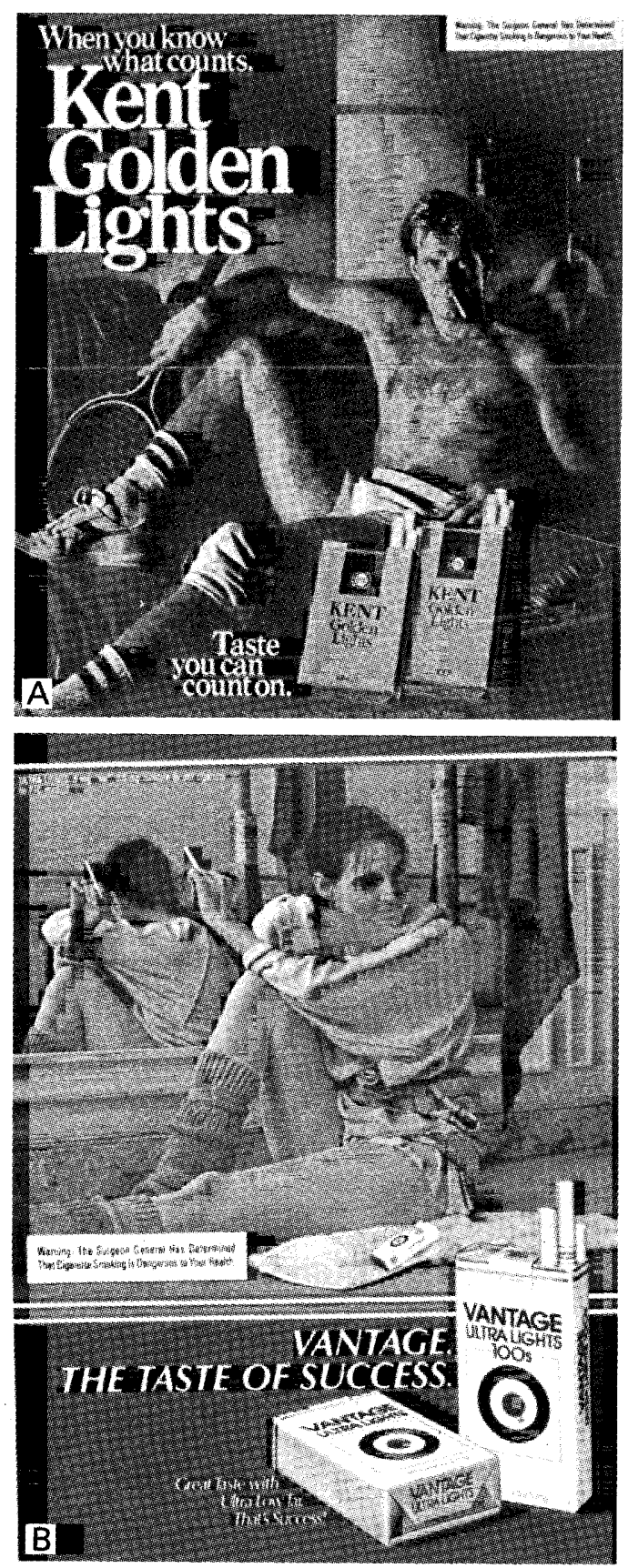

Figure 15 "Cigarette advertising shall not depict as a smoker any person participating in, or obviously having just participated in, physical activity requiring stamina or athletic conditioning beyond that of normal recreation."

Tennis and ballet are hardly activities that would be classified as "normal recreation" for adult smokers.

king-size cigarette."(1953). ${ }^{68}$ The very notion of a "filter" on a cigarette suggests that harmful things will be "filtered out", and therefore will not reach the person who is smoking the cigarette. During 1968, the Liggett and Myers Tobacco Company introduced Lark cigarettes with a granulated charcoal filter. The advertising campaign highlighted the danger of poison gas in cigarette smoke, and positioned Lark as the solution. The campaign was inaugurated with an advertisement in the form of a press release from the American Medical Association convention (figure 16), inaccurately implying that organisation's endorsement.

Lorillard apparently withdrew from the code to launch True, as did American Tobacco to launch Carlton. ${ }^{69} 70$ Ten years later, the Brown

\section{GAS IN CIGARETTE SMOKE MAY BE A BIGGER PROBLEM THAN TAR AND NICOTINE, AMERICAN MEDICAL ASS'N.TOLD.}

San Francisco, June 19: (As reported by major newspapers and wire services) The A.M.A. Convention was told by an important medical researcher from one of the major U.S. universities that the real problem may be in the gas content of cigarette smoke and not "tar" and nicotine.

\section{ONLY LARK HAS THE GAS-TRAP FILTER.}

Lark's unique Gas-Trap Filter (U.S. Patent No. 3,251,365) reduces certain harsh gases by nearly twice as much as any other popular brand. The reduction of these gases gives Lark a smooth taste no other cigarette can imitate.

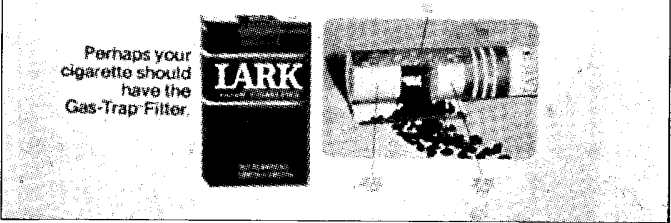

Figure 16 An "important medical researcher" from a "major US university" told the "American Medical Association convention" about "Lark's Unique Gas-Trap Filter", which "reduces harsh gases".

and Williamson Tobacco Company introduced Fact cigarettes with a similar "gas" theme. A typical 1977 advertisement read:

"FACT: If you're concerned about smoking, you should know something about gas. You might not know it, but cigarette smoke is mostly gas-many different kinds. Not just tar and nicotine. And despite what we tobacco people think, some critics of smoking say it's just as important to cut down on some gases as it is to lower tar and nicotine. No ordinary cigarette does both. But FACT does. FACT is the first cigarette with the revolutionary Purite filter. And FACT reduced gas concentration while it reduces tar and nicotine. . . . And that's not just fiction. That's a fact."

During the 1960s, 70s, and 80s, cigarette manufacturers played a confusing numbers game to convince smokers that smoking their brand was a safe alternative to quitting. ${ }^{71}$ Each of several brands claimed to be "lowest" in tar and nicotine, often simultaneously. Implicit in these claims was that some brands were safe, or at least safer:

"I like to smoke, and what I like is a cigarette that isn't timid on taste. But I'm not living in some ivory tower. I hear the things being said against high-tar smoking as well as the next guy and I started looking for a low-tar smoke that had some honest-togoodness taste. ..."

"All the fuss about smoking got me thinking I'd quit or smoke True. I smoke True."

"I'm not too big in the willpower department. But I lost 700 milligrams of tar the first week on what I call the 'Doral diet'."

Today, the battle between Now cigarettes (RJR Nabisco) and Carlton (American Tobacco) is based upon competing and mutually contradictory claims of being lowest in tar and nicotine. In the context of these advertise- 
ments, the word "lowest" is intended to convey that these brands are "safest". Philip Morris entered this market with Next as a "de-nicotinised" cigarette. The implication is that, like decaffeinated coffee, Next is somehow safer. With secondhand smoke becoming more of a health issue, it should be no surprise that many tobacco companies in the late 1980s began offering "low smoke" cigarettes. The thin cigarettes were designed to emit less sidestream smoke. RJ Reynolds introduced the first "smokeless cigarette", Premier, and positioned it as a "cleaner" cigarette. Although it was not a commercial success, modifications were made and its successor, Eclipse, has recently been introduced into test markets in the US. It too is positioned as a cleaner cigarette because the gasses it emits are purported to be invisible and odourless. Less sidestream smoke has also been touted in advertisements for two other cigarette brands-Vantage Excel and Superslims.

\section{Code addition}

"[Prohibits cigarette advertising] on billboards located within 500 feet (152 metres) of any elementary school, junior high school of high school or any children's playground."

\section{Violation}

This code provision does not apply to the advertisements on public buses and subways that children ride to school; the advertisements on store fronts and displays across the street from schools; or the large trucks, with their sides painted with billboard-sized cigarette advertisements, seen parked near playgrounds in Boston and New York. ${ }^{72}{ }^{73}$ Nevertheless, if, as the tobacco industry claims, cigarette advertising has no impact on children, then one must ask what difference it makes if cigarette billboards are within 500 feet of a school or playground or even on the playground?

\section{Conclusions}

During the past 30 years the tobacco industry has adopted, dismantled, and revised its volun-

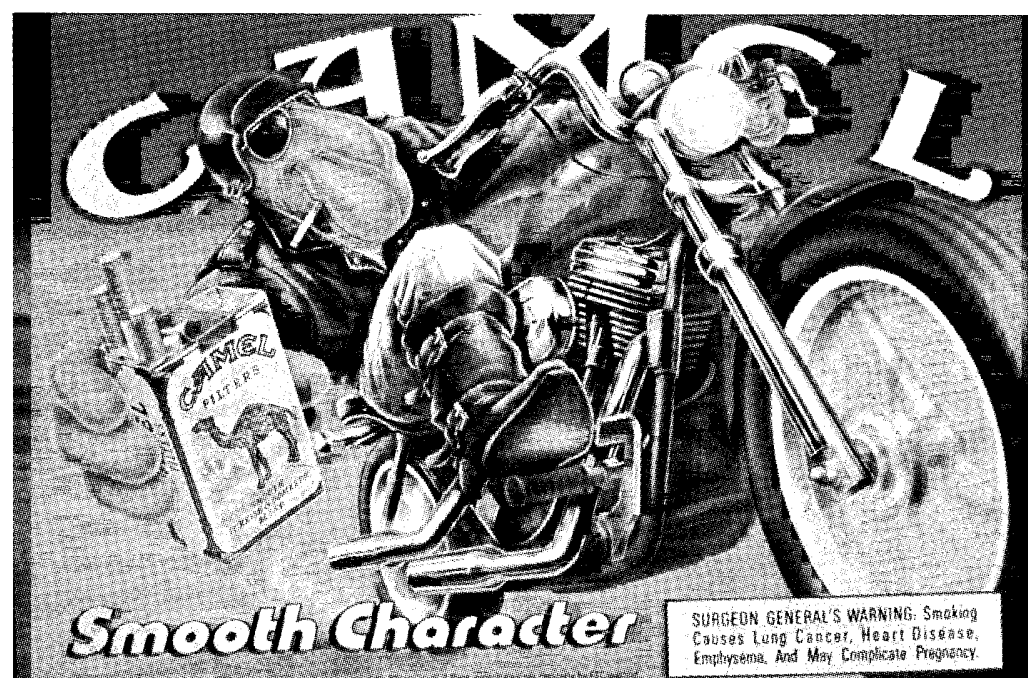

Figure 17 The industry has resurrected the use of cartoons to promote their brands. Here, $R \mathscr{f} R$ Nabisco uses Old foe Camel to promote cigarettes. This brings 30 years of tobacco advertising from the Flintstones full circle. tary code, during which time individuals companies have withdrawn and rejoined the code. Through it all, the industry collectively haso regularly violated many (if not most) of the provisions of the code. Research lookinge specifically at broadcast media advertising concluded "Both the Tobacco Institute and the NAB (National Association of Broadcasters) failed in their nominal efforts to restrain theo cigarette industry from the inducements of tel-들 evision advertising for cigarettes."74

The goals of the original code as stated in 1964 are appropriate today: to prevents advertising that would influence children and to avoid advertising that makes unfounded? claims. Unlike 1964, today there is sufficien $\vec{\omega}$ research to indicate that tobacco advertising plays an important role in smoking decisions by children. And disturbingly, smoking is orf the rise among young people in the US; smokis ing prevalence increased in 1995 for the fourther consecutive year among eighth- and tenthgraders (13-16 years old), and for the thirdconsecutive year among high school seniorso (17-18 years old). ${ }^{7}$

The industry has come full circle since the 1960s when the cartoon character Fred? Flintstone promoted Winston. Today, the rak- $\overrightarrow{0}$ ish Old Joe cartoon character effectively sellso Camel (figure 17) and Willy the Penguin has been introduced as the hip spokesman for Koo (figure 18).

Ironically, the tobacco industry's voluntaryฏ Cigarette Advertising Code as written in $1964 \mathrm{D}$ was actually more restrictive than the regulations that are now enforced by the FTC응 It is obvious, however, that the industry does? not adhere to its own codes. We have witnessect more than three decades without progress. In

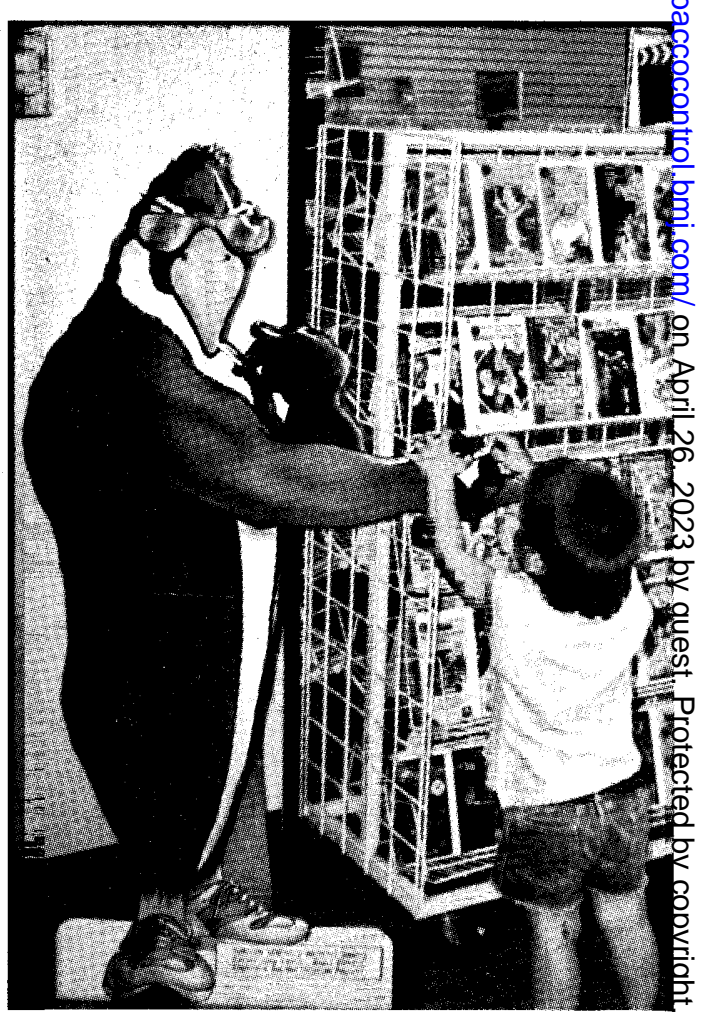

Figure 18 Brown and Williamson has been test-marketing Willy the Penguin to promote Kool cigarettes. 
fact, with the cartoon characters and adventure themes reaching children in youth-oriented media, the situation is probably worse today than it was in 1964. It appears to be the same story in other countries as well. ${ }^{767}$ Michael Daube $^{77}$ perhaps said it best:

"Around the world, voluntary agreements fail and fail again for the simple reason that they were never intended to succeed. The tobacco industry only willingly accepts agreements that it knows to be worthless. These agreements suffer from some or all of the following failings: no body has authority to enforce them; if an independent body is charged with their enforcement, that body (which often includes direct or indirect representatives of the industry) will not take any firm action; the rules do not proscribe some of the industry's worst excesses; the wording of agreements is loosely phrased, with 'weasel words', so as to allow many different interpretations; much depends on interpretation of the 'spirit' as well as the letter of the agreements and the 'spirit' is always interpreted to favour the industry; the agreements cover certain forms of direct brand advertising only and usually not, for example, company advertising, advertising connected with sports sponsorship, or many other forms of sales promotion; the codes are framed without any regard to the extensive literature now available about influences on children and young people; no attention is paid to the quantum of advertising; there are no penalties for breach of the agreements; the agreements are so ill publicised that there are few complaints; investigation of complaints takes so long that the offending advertisements have ceased long before any decision is reached; and in the rare event that a tobacco company is criticised by the controlling body, for current advertising, the company simply carries on regardless."

In 1967, Senator Robert Kennedy stated, "We have intrusted a charade of proposed selfregulation for some years. The codes of self-regulation have been largely ineffective, and I see little hope for change. ${ }^{78}$ In 1967, the FTC declared that "Self-regulation by the industry has proved to be ineffectual." In 1969, the FTC reported to Congress that it was futile to rely "upon voluntary regulation of cigarette advertising to achieve any significant change in the content and meaning of cigarette advertising." "79 In 1981, the FTC stated, "In light of the cigarette industry's position that smoking does not pose a hazard to health, that its current advertising practices do not pose any problems, and that the public is already well-informed, combined with the industry's failure to regulate itself in the past, voluntary industry self-regulation does not appear to be a reasonable alternative as a remedy to the current problems in cigarette advertisements." " In 1991 Senator Henry Waxman said "Cigarette advertising is the moral equivalent of a national campaign to 'Drive Drunk-just for the fun of it'." ${ }^{81}$

It is clearly time for government to do what voluntary codes have not, can not, and will never do. The Institute of Medicine has concluded: "Whether or not youths are a targeted market segment, advertisements present images that appeal to children and youths and are seen and remembered by them. . . . Research suggests that, regardless of intent, marketing pitches purported to be aimed at young adults ages 20 to 25 are also appealing to youths." ${ }^{\text {82 }}$ The American Academy of Pediatrics concluded: "There should be a ban on all tobacco and alcohol advertising in all media. This ban should include all 'passive' advertising in sponsored sports events (ie, banners, logos, etc)." ${ }^{83}$ The US Food and Drug Administration has promulgated restrictions on sale and distribution to persons under 18, as well as on advertising and promotion to include format, content, and the use of non-tobacco items to promote tobacco products. ${ }^{84}$ Although these rules, if they survive legal challenge and are enforced exactly as written, would be an improvement, they still fall short of what is needed to prevent the promotion of tobacco products.

The mandate should be clear, given what we know about the health consequences of smoking, what we know and suspect about the effects of cigarette advertising on children, what we know about the tobacco industry's compliance with voluntary codes in the United States and other countries, and what we know from studying the history of the tobacco industry relative to its response to any type of regulation - that is, act offended that anyone would suspect them of any wrongdoing, buy time through editorial and paid advertising to debate the issues, buy legislative support for their position through hard and soft campaign contributions, compromise to avoid meaningful regulation, and block enforcement and/or circumvent the intent of the rules.

There is only one approach that has any chance of decreasing smoking among young people. It is simple, obvious, easy to monitor and enforce; yet, remarkably, it has never been tried. There should be an immediate halt to all tobacco advertising and promotion of any type until such a time as the tobacco industry proves beyond a shadow of doubt that these activities do not lead to tobacco use by children or cause the adult population to be misinformed about the consequences of tobacco use. There must be no more compromises. There can be no further working with the tobacco industry to devise yet another plan that will not be effective either.

The only beneficiaries of continuing tobacco advertising and promotion in any format are the tobacco industry and those who feed off its profits. Everyone else in the world will benefit from a total ban of its promotion. To be fair, if in time, the tobacco industry does prove that advertising and promotion do not influence young people, and that adult smokers are making a fully informed decision regarding using tobacco products, using the same high standards the tobacco industry invokes for studies that would be necessary to prove to the tobacco industry that smoking does cause disease, then the Tobacco Industry's Code of Advertising, as stated in 1996, could be placed into law with a prospective reviewing process, appropriate enforcement mechanisms, industry funding, and meaningful rapid penalties for violations.

1 US Subcommittee on Health and the Environment. Advertising of tobacco products. Report to the Committee on 
Energy and Commerce, House of Representatives, Serial No. 99-167, 18 Jul, 1 Aug 1986.

2 RJ Reynolds Tobacco Company Research Department. Secret planning assumptions and forecast for the period 19761986. 15 Mar 1976

3 DiFranza JR, Richards JW, Paulman PM, et al. RJR Nabisco's cartoon camel promotes Camel cigarettes to children. $\mathcal{F} A M A$ 1991;266:3149-53.

4 Pierce JP, Gikin E, Burns DM, et al. Does tobacco advertising target young people to start smoking? $\mathcal{F} A M A$ 1991;266:3154-8.

5 Seldon BH, Dordoodian K. A simultaneous model of cigarette advertising: effects on demand and industry response to public policy. Rev Econ Stat 1989;71:673-7

6 Chapman S, Fitzgerald B. Brand preference and advertising recall in adolescent smokers: some implications for health promotion. Am $\mathcal{F}$ Public Health 1982;72:491-4.

7 Aitken PP, Eadie DR. Reinforcing effects of cigarette advertising on underage smoking. $B r \mathcal{F}$ Addict 1990;85:399-412.

8 Pollay RW, Siddarth S, Siegel M, et al. The last straw? Cigarette advertising and realized market shares among youth and adults, 1979-1993. F Marketing 1996;60(Apr):1-16.

9 Fischer PM, Schwartz MP, Richards JW, Goldstein AO Rojas TH. Brand logo recognition by children aged 3 to 6 years: Mickey Mouse and Old Joe the Camel. $\mathcal{F} A M A$ 1991;266:3145-8.

10 Bart P. Cigarette makers adopt an industry code for advertising. New York Times 1964 Apr 28:1

11 Tobacco Institute. Cigarette advertising and promotion code Washington, DC: Tobacco Institute, 1990 (1875 I Street, NW, Washington, DC 20006, USA).

12 Slade J. Learning to fight nicotina tobacco. $\mathrm{NF} \mathrm{Med}$ 1988;85:102-6.

13 Tye JB, ed. Sixty years of deception: an analysis and compilation of cigarette advertising, 1925-1985 (Vol 4: 1964 1973). Palo Alto, California: Health Advocacy Center, 1986 (511 East Columbus Avenue, Springfield, Massachusettes 01105 , USA)

14 Is there a way to smoke? Consumer Reports $1968 \mathrm{Feb}$ 97-103.

15 Pollay RW. Propaganda, puffing and the public interest: the scientific smoke screen for cigarettes, Public Relations Review 1990;16:27-42.

16 Spears AW (Lorillard). Memorandum to Judge $\mathrm{CH}$. Re CTR; dated 24 Jun 1974

17 Morgan JJ. Memorandum to Cullman H, Bowling JC (Philip Morris); dated 24 Mar 1981

18 Pollay RW. Exposure of US youth to cigarette television advertising in the 1960s. Tobacco Control 1994;3:130-3.

19 Anon. Cigarette controls: a sick joke so far. Consumer Reports 1968 Feb:97-103.

20 Easy on the drawback. Time 1954 May 31:70.

21 Smoking more, despite the scare. Business Week 1962 Dec 22:77-80.

22 Cigarette smokers still puffing away. Business Week 1963 Dec 14:148-50

23 US Public Health Service. Smoking and health. Report of the Advisory Committee to the Surgeon General. Washington, DC: Department of Health, Education and Welfare (PHS Publication No 1103.) Public Health Service, 1964.

24 US Federal Trade Commission. Vacation of warning requirement in trade regulation rule concerning advertising and labeling of cigarettes. Federal Register 1965;30(Jul 28): 9494 .

25 New brands, tastes spur cigarette sales. Business Week 1965 Dec:64-8.

26 US Federal Trade Commission. Report to Congress pursuant to the Federal Cigarette Labeling and Advertising Act, 1986. Washington, DC: Federal Trade Commission, May 1988.

27 Carter PC. Tobacco ad code ignored (letter). Advertising Age 1996 Oct $28: 26,28$

28 Mazis MB, Ringold DJ, Perry ES, Denman DW. Perceived age and attractiveness of models in cigarette advertisements. F Marketing 1992;56:22-37.

29 Basil MD, Schooler C, Altman DG, Slater M, Albright CL, Maccaby N. How cigarettes are advertised in magazines: special messages for special markets. Health Comm 1991;3:75-91.

30 Albright CL, Altman DG, Slater MD, Maccaby $N$ Cigarette advertising in magazines: evidence for a
differential focus on women's and youth magazines. Health Educ Q 1988;15:225-33.

31 Connolley D. Kid's concept of the cigarette code. $f A M A$ 1991;266:3126.

32 Anon. Tobacco Wars. Mother fones, 1996 May/Jun 1996:48.

33 Blum A. Marlboro Grand Prix circumvention of the television ban on tobacco advertising. $N$ Engl $f$ Med 1991; 324:913-17.

34 Anon. 1989 CART/PPG Indy Car year end report. Sponsors report, Championship Auto Racing Team 1989;7(19):1 8.

35 Hwang SL. Philip Morris agrees to stop placing ads in view of TV. New York Times 1995 Jun 7:B1,B8

36 Lardman J, Considine M. Giving the name away; product placement in popular cinema. Australia: QUIT \& Australian Teachers of Media, 1992:15.

37 Wilson MG. Letter to Luken TA, 1989 Jul 19. URL <www.library.ucsf.edu/tobacco/docs/html 2406.06.01>.

38 Kovoloff RH. How to cast your product in the movies. Associated Film Promotions brochure.

39 Bergman C. Tobacco's cloudy image on the silver screen. Christian Science Monitor, 1989 Jul 28:9.

40 Colford SW. Tobacco groups end paid placements. Advertising Age 1990 Dec 17:31.
41 Domatay NV. Letter to Kovoloff R. URL: <www.library.ucsf.edu/tobacco/docs/html2400.06>.

42 Okie S. Cigarette logos in video arcade games prompt complaints. Washington Post 1990 Mar 13:8A.

43 "Hypersell" latest game at the video arcade. DOC News an Views 1990 Winter: 12

44 McCarthy MJ. Tobacco critics see a subtle sell to kids. Wa Street fournal 1990 May 3:B1

45 Rosen, D. Statement from SEGA of America, Inc. Ketchem Communications, 1990 Jan 12.

46 Davis RM. Cigarette advertising in video arcades. Tobacc Control 1992;1:131-3.

47 Newport targets children with basketball game. Smokefree Air 1991 Autumn:6.

48 Anon. Corporate Crime Reporter 1991 Mar 4:65-6.

49 Denny O'Neil, ed. Batman No. 485. New York: DC Comics October 1992:9.

50 Jensen T. Dead Superman may revive DC Comics, Advertis ing Age 1992 Nov:3.

51 Goldstein A, Richards JW. From the Centers for Disease Control: Cigarette advertising-United States, 1988? FAMA 1990;263:2874-5

52 Davis RM, Jason LA. The distribution of free cigarette sam ples to minors. Am f Prev Med 1988;4:21-6.

53 Goldstein A, Klein JD, Richards JW Jr, Fischer PM Tobacco coupons and teenagers. $7 A M A$ 1991;265:1259.

54 DiFranza J. Smokeless tobacco company accused of mailing children free samples. Athal (Massachusetts) Daily News 1989 Sep 7:16

55 Joe's Camel tracks. Mother fones 1996 May/Jun:44

56 Richards JW, DiFranza, Fletcher C, Fischer PM. RP Reynolds "Camel Cash": Another way to reach kids. Tobacco Control 1995;4:258-60.

57 Sumner W, Dillman DG. A fist full of coupons: cigarette continuity programmes. Tobacco Control 1995;4:245-52. त

58 Coeytaux RR, Altman DG, Slade J. Tobacco promotions in the hands of youth. Tobacco Control 1995;4:253-7.

59 Transcript of Tobacco Under Fire. Documentary for Turning Point, not yet aired on ABC.

60 Nelson JR. Letter. Wall Street fournal 1990 Jun 12

61 Anon. Women's tennis. USA Today 1986 Jan 16:9A

62 Anon. Legends of NASCAR Vol 1. Charlotte, North Carolina: Vortex Comics, Inc, Jun 1991.

63 Anon. Adventures of NASCUBS. Charlotte, North Carolina New Image and MMI, June 1991.

64 Christen AG. The case against smokeless tobacco: Five facts for the health professional to consider. $\mathcal{F}$ Am Dent Assof 1980;101:464-9.

65 Connolly GN. The marketing of nicotine addiction by on oral snuff manufacturer. Tobacco Control 1995;4:73-9.

66 Palmer AB. Some variables contributing to the onset of cigarette smoking among junior high students. Soc Sci Med 1970;4:359-66

67 Warner KE. Tobacco industry responds to public health concern: a content analysis of cigarette ads. Health Educ $\$$

1985;12:115-27.
68 Anon. Advertising themes for Viceroy. URL? <www.library.ucsf.edu/tobacco/docs/html1700.04>.

69 Withdrawal by American imperils tobacco code. Advertising Age 1967;38:1,55.

70 Christopher $M$. Six cigarette marketers rally round ad code Advertising Age 1967;38:1,113

71 Tye J, Slade J. Tar wars escalate as cigarette ads promise smoker safety. Tobacco \& Youth Reporter 1989 Autumn:18응 19.

72 Connolly GN. Affidavit. Commonwealth of Massachusetts, Superior Court Department, Civil Action No 90-4226 Superior Cour
1990 Jun 8.

73 Anon. Butt Mobile in NYC. Smokefree Air 1991 Autumn:6

74 Pollay RW. Promises, promises: self regulation of US cigarette broadcast advertising in the $1960 \mathrm{~s}$. Tobacco Con trol 1994;3:134-41.

75 Anon. Cigarette smoking among American teens rises again in 1995 (press release). Ann Arbor, Michigan: University. of Michigan Survey Research Center, 15 Dec 1995.

76 Mindell, TS. The UK voluntary agreement on tobacco advertising: a comatose policy? Tobacco Control 1993 2:209-14.

77 Daube $M$. Voluntary agreements designed to fail. Tobacce Control 1993;2:183-4.

78 Tobacco and health. Proceedings of the first world conference on tobacco and health, 1967. New York: American Cancero Society:7

79 US Federal Trade Commission. Report to Congress: pursue ant to the Federal Cigarette Labeling and Advertising Act: Washington, DC: Federal Trade Commission, 1969:27.

80 Myers ML, Isco C, Jennings C, Lenox W, Minksy E, Sack A. Federal Trade Commission Staff Report on the cigaretteD Commission, 1981:5-10-5-16. 81 Waxman $H$. Tobacco marketing profiteering from children $\frac{\varrho}{f \sigma}$

82 Lynch BS, Bonnie RJ, eds. Growing up tobacco free: preventing nicotine addiction in children and youths. Washington, DCO National Academy Press, 1994.

83 Committee on Communications. Children, adolescents an advertising. Pediatrics 1995;95: Feb 1:295-297.

84 US Food and Drug Administration. Regulations restricting the sale and distribution of cigarettes and smokeless tobacco to protect children and adolescents. Federal Register 1996;61(28 Aug):44396-5318. 


\section{Appendix 1: Original Cigarette Advertising and Promotion Code}

The text of the tobacco industry's original voluntary cigarette advertising code as it appeared in the New York Times on 28 April 1964.

\section{Statement of purposes}

The purposes of this Code are to establish uniform standards for cigarette advertising and to provide means whereby compliance with this Code can be ascertained promptly and fairly and on a consistent basis.

\section{Article I}

DEFINITIONS

Section 1 "Advertising"

(a) Means all forms of advertising in, or primarily directed to, the United States, Puerto Rico, any territory or possession of the United States, or any military installation of the United States including but not limited to, radio, television and cinema commercials of all types, newspaper and magazines advertisements, billboards, posters and signs, subway and rail or bus car cards, automobile and truck decals, posters and signs, calendars, pamphlets, handbills, matchbook advertising, and point of sale display material of all types;

(b) Includes any written material or article or excerpt there from not otherwise advertising when used for promotional purposes;

(c) Includes labelling, namely, the display of graphic matter upon any portion of the package, carton, or other container in which cigarettes are packages or shipped by the manufacturer; but

(d) Does not include the entertainment portion of any television or radio program.

\section{Section 2 "Representation"}

Means any statement, references or claim, express or implied, direct or indirect, whether in oral, written, printed or graphic form, or in any combination of such forms.

\section{Article II}

THE CODE ADMINISTRATOR

Section 1 There shall be a Code Administrator who shall be a person of recognized independence, integrity and intellectual achievement to the end that decision by him shall command public confidence and respect. The Administrator shall have all of the powers and authority necessary and proper to enable him to discharge effectively the responsibility entrusted to him by this Code.

Section 2 The Administrator shall have complete and final authority to determine whether cigarette advertising complies with the standards of this Code and to enforce this Code in all other respects.

Section 3 The Administrator shall appoint a staff adequate and competent to assist him in discharging his duties.
Section 4 Neither the Administrator nor any member of his staff shall be an officer, director, employee or stockholder of any manufacturer of tobacco products, not shall any such person have any financial interest in the business of any such manufacturer.

Section 5 The Administrator is authorized to convene scientific advisory panels to enable him to carry out his duties. Persons selected for such panels shall be of independence, integrity and competence in their particular areas of scientific discipline. In selecting such persons, the Administrator may consult with appropriate governmental and private agencies such as the US Department of Health, Education and Welfare; National Academy of Science; National Research Council; American Medical Association; Scientific Advisory Board of the Council for Tobacco Research-USA; medical and scientific societies; colleges and universities; and non-profit research institutes.

Section 6 The Administrator shall by regulation establish procedures for the administration and enforcement of this Code including, without limitation, procedure for:

(a) The submission to him of proposed cigarette advertising which, together with any supporting data or documents, shall be kept confidential, except as otherwise provided in Article IV, Section 4, of this Code or as agreed to by the submitting party:

(b) The submission of protests by parties subject to this Code concerning any determination by him;

(c) Hearings in connection with all submission and protests; and

(d) Reconsideration by him of any of his determinations.

\section{Article III}

ADVERTISING CLEARANCE

Section 1 No cigarette advertising shall be used unless such advertising shall first have been submitted to the Administrator and determined by him to be in compliance with the standards of this Code; provided that by regulation promulgated by the Administrator specified advertising may be excepted from the requirement of such submission but not from the requirement of compliance with the standards of this Code.

\section{Article IV}

ADVERTISING STANDARDS

Section 1 All cigarette advertising and promotional activities shall be subject to the following:

(a) Cigarette advertising shall not appear (i) On television and radio programs, or in publications, directed primarily to persons under twenty-one years of age; (ii) In spot 
announcements during any program break in, or during the program break immediately preceding or following a television or radio program directed primarily to persons under twenty-one years of age, (iii) in school, college, or university media (including athletic, theatrical and other programs); (iv) in comic books, or comic supplements to newspapers.

(b) Sample cigarettes shall not be distributed to persons under twenty-one years of age.

(c) No sample cigarettes shall be distributed or promotional efforts conducted on school, college, or university campuses, or in their facilities or in fraternity or sorority houses.

(d) Cigarette advertising shall not represent that cigarette smoking is essential to social prominence, distinction, success or sexual attraction.

(e) Natural persons depicted as smokers in cigarette advertising shall be at least twenty-five years of age and shall not be dressed or otherwise made to appear less than twenty-five years of age, fictitious persons so depicted in the form of drawings, sketches or any other manner shall appear to be at least twenty-five years of age in dress and otherwise.

(f) Cigarette advertising may use attractive, healthy looking models, or illustrations or drawings of persons who appear to be attractive and healthy, provided that there is no suggestion that their attractive appearance or good health is due to cigarette smoking.

(g) No cigarette advertising shall contain a picture or an illustration of a person smoking in an exaggerated manner.

(h) Cigarette advertising shall not depict as a smoker any person well known as being, or having been an athlete.

(i) Cigarette advertising shall not depict as a smoker any person participating in, or obviously having just participated in, physician [sic] activity requiring stamina or athletic conditioning beyond that of normal recreation.

(j) Testimonials from athletes or celebrities in the entertainment world, or testimonials from other persons, who in the judgement of the Administrator, would have special appeal to the persons under twenty-one years of age, shall not be used in cigarette advertising.

Section 2 No cigarette advertising which makes a representation with respect to health shall be used unless;

(a) The Administration shall have determined that such representation is significant in terms of health and is based on adequate relevant and valid scientific data; or

(b) If the Administrator shall have determined it to be appropriate, a disclaimer as to significance in terms of health shall be set forth in such advertising in substance and form satisfactory to the Administrator; or

(c) The Administrator shall have determined that the representation with respect to health in such advertising is not material,
Section 3 The inclusion in cigarette advertising of reference to the presence or absence of a filter, or the description or depiction of a filtero shall not be deemed a representation with respect to health unless the advertising includ윽 ing such reference, description shall be흘 determined by the Administrator to constitute through omission or inclusion, a representations? with respect to health. If the Administratore shall have determined that such advertising constitutes a representation with respect to health, the provisions of Section 2 of this article shall apply.

Section 4 No cigarette advertising shall be usedwhich refers to the removal or the reduction of any ingredient in the mainstream smoke of $\overrightarrow{a \omega}$ cigarette, except that it shall be permissible tos make a representation as to the quality of an ingredient present in the mainstream smoke or as to the removal in toto of an ingredient fromte the mainstream smoke, or as to the absence of an ingredient normally present in the mainstream smoke if;

(a) The Administrator shall have determined that such representation is significant in terms of health and is based on adequate्ष्ठ relevant and valid scientific data; or

(b) A disclosure as to significance in terms of health shall be set forth in such advertisingo in substance and form satisfactory to the Administrator; or

(c) The Administrator shall have determine that a disclaimer is unnecessary for the reason that the representative in such advertising has no health implication or that such implication is not material; and 3

(d) The quality of such ingredient is determined and expressed in accordance. with uniform standards adopted by the Administrator for measuring the quantity of the ingredient present in then mainstream smoke, provided that untif such uniform standard is so adopted, the quantity of such ingredients may be deter $\underline{0}$ mined and expressed in accordance with? any recognized scientifically valid methoc disclosed to the Administrator without any? requirement of confidential treatment.

Section 5 Any advertising determined by the Administrator to be in conformity with the Code may include the following legend: "This advertising (label) conforms to the standards of the Cigarette Advertising Code."

\section{Article V}

PROCEDURES IN EVENT OF VIOLATION OF CODE Section 1 Any person, firm or corporation sub? ject to this Code, who violates any provision of this Code shall, in the discretion of the Admin istrator with respect to each such violation, pays to the office of the Administrator as liquidated $\mathbb{D}$ damages, and not as a penalty, a sum not t@ exceed One Hundred Thousand Dollars? $(\$ 100,000)$, as determined by the Administra을 tor after consideration by him of all relevanf facts. The Administrator shall establish regula? tions for the determination of such violation and for the assessment and payment of such damages. No sanction shall be imposed 
without affording a hearing to the alleged violator. Upon written request from the Administrator, an alleged violator of the Code shall promptly deliver to the Administrator any material and documents in its possession which are relevant and material to a determination by the Administrator as to whether the Code had been violated.
Section 2 Nothing herein contained shall be construed to give any person, firm or corporation, other than the Administrator any cause of action.

Section 3 In the event of a violation of this Code, the Administrator in his discretion may make public the fact of such violation in such manner as he may deem appropriate.

\section{Appendix 2: Current Cigarette Advertising and Promotion Code}

The text of the tobacco industry's current voluntary cigarette advertising code as it appears in a pamphlet obtained from the Tobacco Institute.

\section{Cigarette Advertising and Promotion Code}

Cigarette smoking is an adult custom. Children should not smoke. Laws prohibiting the sale of cigarettes to minors should be strictly enforced. The cigarette manufacturers advertise and promote their products only to adult smokers. They support the enactment and enforcement of state laws prohibiting the sale of cigarettes to persons under 18 years of age.

The cigarette manufacturers have adopted the following Code to emphasize their policy that smoking is solely for adults.

This Code, as set forth below, combines (1) the provisions of the original Cigarette Advertising Code of 1964, as restated in 1982; (2) the Code of Cigarette Sampling Practices of 1981, as amended in 1983; and (3) the additional restrictions on cigarette advertising and promotion adopted by the industry in 1990 .

\section{Advertising}

1. Cigarette advertising shall not appear-

(a) in publications directed primarily to those under 21 years of age, including school, college or university media (such as athletic, theatrical or other programs), comic books or comic supplements; or

(b) on billboards located within 500 feet of any elementary school, junior high school or high school or any children's playground.

2. No payment shall be made by any cigarette manufacturer or any agent thereof for the placement of any cigarette, cigarette package, or cigarette advertisement as a prop in any movie produced for viewing by the general public.

3. No one depicted in cigarette advertising shall be or appear to be under 25 years of age.

4. Cigarette advertising shall not suggest that smoking is essential to social prominence, distinction, success or sexual attraction, nor shall it picture a person smoking in an exaggerated manner.

5. Cigarette advertising may picture attractive, healthy looking persons provided there is no suggestions that their attractiveness and good health is due to cigarette smoking.

6. Cigarette advertising shall not depict as a smoker anyone who is or has been well known as an athlete, nor shall it show any smoker participating in, or obviously just having participated in, a physical activity requiring stamina or athletic conditioning beyond that of normal recreation.

7. No sports or celebrity testimonials shall be used or those of others who would have special appeal to persons under 21 years of age.

\section{Sampling}

1. Persons who engage in sampling shall refuse to give a sample to any person whom they know to be under 21 years of age or who, without reasonable identification to the contrary, appears to be less than 21 years of age.

2. Sampling shall not be conducted in or on public streets, sidewalks or parks, except in places that are open only to persons to whom cigarettes lawfully may be sold.

3. Cigarette product samples shall not otherwise be distributed in any public place within two blocks of any centers of youth activities, such as playgrounds, schools, college campuses, or fraternity or sorority houses.

4. The mails shall not be used to distribute unsolicited cigarette samples.

5. Cigarette samples shall not be distributed by mail without written, signed certification that the addressee is 21 years of age or older, a smoker and wishes to receive a product sample.

6. Cigarette samples shall not be distributed in direct response to requests by telephone.

7. Persons who engage in sampling shall not urge any adult 21 years of age or over to accept a sample if the adult declines or refuses to accept such sample.

8. Persons who engage in sampling shall indicate by oral or written means that samples are intended for smokers. 
9. No cigarette samples shall be distributed by a sampler in a public place to any person in a vehicle.

10. Persons distributing cigarette samples shall secure their stocks of samples in safe locations to avoid inadvertent distribution of samples contrary to these provisions.

11. Persons distributing cigarette samples shall avoid blocking or otherwise significantly impairing the flow of pedestrian traffic.

12. In the event that circumstances arise at a particular location that make it unlikely that sampling can be conducted in a manner consistent with the provisions of this Code, sampling shall be stopped at that location until such circumstances abate.

13. Persons distributing samples shall promptly dispose of empty sample boxes and shall take reasonable steps to ensure that no litter remains in the immediate area of sampling as a result of sampling activities.

14. Each cigarette manufacturer shall impose by contract on all independent contractors who conduct cigarette sampling on the manufacturer's behalf a set of sampling standards no less stringent than those contained in this Code. In addition, each cigarette manufacturer shall require such sampling contractors to inform all personnel employed by the contractor who engage in sample activities, both orally and in writing.

15. Persons who engage in sampling shall be monitored on a periodic basis by supervisory personnel of the cigarette manufacturer and/or independent contractor for whom the sampling activities are being conducted to ensure compliance with the provisions of this Code concerning cigarette sampling.
16. Each cigarette manufacturer shall take all reasonable steps to ensure that any person who engages in sampling and knowingl $\mathrm{P}^{-1}$ violates any of the provisions of this Code concerning cigarette sampling shall be dis? charged from employment as a cigarette sampler.

\section{Other Promotional Activities}

1. There shall be no mail distribution oई nontobacco premium items bearing ciga $\frac{\bar{p}}{\frac{1}{}}$ rette brand names, logos, etc., without writo ten, signed certification that the addressee i\& 21 years of age or older, a smoker and wishes to receive the premium.

2. There shall be no other distribution of

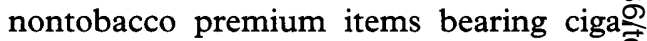
rette brand names, logos, etc., except with the purchase of a package or carton of cigat rettes or to persons 21 years of age or olderico

3. Clothing bearing cigarette brand names of logos shall be in adult sizes only.

\section{Definitions}

1. "Advertising" means all forms of advertis $\Phi^{\circ}$ ing including vehicle decals, posterso pamphlets, matchbook covers and point of purchase materials in the United Statess Puerto Rico, and US territorial possessions?

2. "Sampling" means giving or distributing without charge packages of cigarettes in public place for commercial advertisin purposes ("cigarette samples"), but doe岁 not include isolated offerings of complii⿱ mentary packages or the distribution of such packages to wholesale or retai 3 customers or to company shareholders op employees in the normal course of business?

3. "Public place" includes any street, sidewalk park, plaza, public mall, and the publif areas of shopping centers and office buildings.

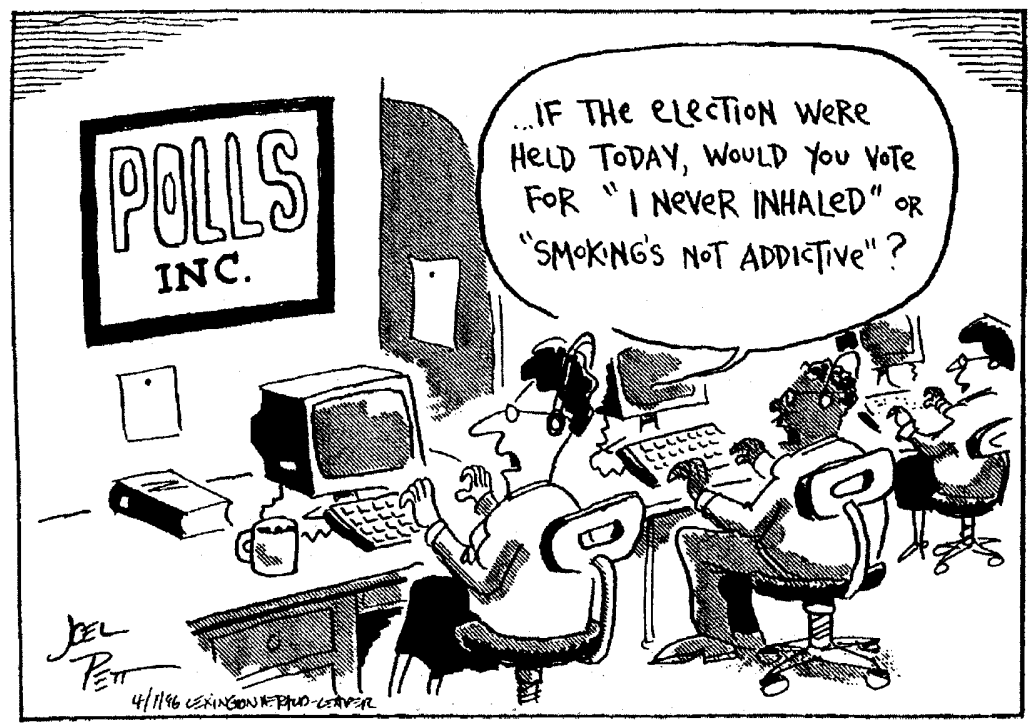

By foel Pett, of the Lexington (Kentucky) Herald-Leader, reprinted with permission. 